\title{
Review Article \\ ErbB Proteins as Molecular Target of Dietary Phytochemicals in Malignant Diseases
}

\author{
Alexandru Filippi, Oana-Alina Ciolac, Constanța Ganea, and Maria-Magdalena Mocanu \\ Department of Biophysics, Carol Davila University of Medicine and Pharmacy, Bucharest, Romania \\ Correspondence should be addressed to Constanța Ganea; constanta.ganea@gmail.com \\ and Maria-Magdalena Mocanu; mocanu.umfcd@gmail.com
}

Received 28 October 2016; Revised 30 December 2016; Accepted 17 January 2017; Published 13 February 2017

Academic Editor: Stefano Cascinu

Copyright (C) 2017 Alexandru Filippi et al. This is an open access article distributed under the Creative Commons Attribution License, which permits unrestricted use, distribution, and reproduction in any medium, provided the original work is properly cited.

\begin{abstract}
ErbB proteins overexpression, in both normal and mutated forms, is associated with invasive forms of cancer prone to metastasis and with stronger antiapoptotic mechanisms and therefore more challenging to treat. Downstream effectors of ErbB receptors mediating these phenotypic traits include MAPK, STAT, and PI3K/AKT/mTOR pathways. Various phytochemical compounds were studied for their large number of biological effects including anticancer activity. Among these compounds, epigallocatechin-3-gallate (EGCG), the main catechin from green tea leaves, and curcumin, component of the curry powder, constituted the object of numerous studies. Both compounds were shown to act directly either on ErbB expression, or on their downstream signaling molecules. In this paper we aim to review the involvement of ErbB proteins in cancer as well as the biologic activity of EGCG and curcumin in ErbB expressing and overexpressing malignancies. The problems arising in the administration of the two compounds due to their reduced bioavailability when orally administered, as well as the progress made in this field, from using novel formulations to improved dosing regimens or improved synthetic analogs, are also discussed.
\end{abstract}

\section{Introduction}

ErbB proteins are part of the receptor tyrosine kinases family and include four members ErbB1 (also known as EGFR, HER1), ErbB2 (Neu, HER2), ErbB3 (HER3), and ErbB4 (HER4). Since the discovery of the first ErbB protein three decades ago, all four members were shown to be involved in cancer when mutated or overexpressed [1]. ErbB positive cancers are generally associated with a poor prognostic $[2,3]$, as ErbB overexpression promotes the migration and invasion of cancer cells [4]. Such actions are mediated through the activation of multiple signaling cascades such as MAPK pathway, Akt, and phospholipase $\mathrm{C} \gamma$ which lead to the overexpression of several protooncogenic transcription factors [5]. All ErbB receptors can form homo- or heterodimers. Depending on the expression levels, ErbB1 receptors might be present mainly in monomeric form at low expression levels, while ErbB2 receptors are usually found predominantly in aggregates of 3 to 8 molecules [6].

ErbB proteins are used now as molecular markers in therapy, since they can be targeted with either tyrosine kinase inhibitors or with specific monoclonal antibodies, for example, cetuximab and panitumumab against ErbB1 or trastuzumab and pertuzumab against ErbB2 $[7,8]$. In spite of the significant success with the use of the monoclonal antibodies in the therapy of ErbB overexpressing cancers, their activity was hindered by the treatment resistance. The resistance to ErbB antibodies may be caused by nuclear localization of ErbB2 [9], miRNA production [10], higher Akt signaling, or steric hindrance by other membrane proteins [11] and raises the need for other therapeutic compounds useful in the treatment of ErbB overexpressing cancers.

Curcumin, a phytochemical constituent of Curcuma longa, used in traditional Ayurveda medicine, is now intensively studied due to its anti-inflammatory [12], antitumor [13], and anti-infectious [14] actions. EGCG is the most active and abundant catechin found in Camellia sinensis leaves, representing about $16.5 \%$ by weight of the water extractable fraction of green tea plants [15]. Among the many actions that EGCG has been shown to exert, are protection against cardiovascular disease [16] and antioxidative [16, 17], antiviral, antibacterial and antifungal [18], and antitumor activities 
TABLE 1: Genomic location and protein attributes of ErbB family [7, 30].

\begin{tabular}{lccc}
\hline ErbB member & Genomic location & Molecular mass $(\mathrm{kDa})$ & Number of amino acids \\
\hline ErbB1 & Chromosome 7 & 134 & 1210 \\
ErbB2 & Chromosome 17 & 138 & 1255 \\
ErbB3 & Chromosome 12 & 148 & 1342 \\
ErbB4 & Chromosome 2 & 147 & 1308 \\
\hline
\end{tabular}

[19]. Both curcumin [20] and EGCG [21] were shown to decrease ErbB2 expression and phosphorylation as well as downstream signaling molecules involved in survival and proliferation of the cancer cells.

\section{ErbB Proteins and Cancer}

ErbB proteins are tyrosine kinase (TK) receptors localized at the plasma membrane level. Up to now, their family includes four members: ErbB1 to ErbB4 and their name was originated from the discovery of avian erythroblastosis viral protein which encoded an abnormal form of epidermal growth factor receptor (EGFR) [5, 22, 23]. A parallel nomenclature for ErbB family frequently used in the scientific field is human epidermal growth factor receptors, HER1 to HER4 [24]. Additionally, a mutated form of ErbB2 has been identified in a chemical induced rodent neuroblastoma and the nucleotide sequence able to produce transformation was named Neu [25, 26]. However, in human breast or gastric cancer ErbB2 gene was found rather amplified and not mutated [27-29]. The genes responsible for ErbB family production are part of the four homebox (Hox) clusters localized on different chromosomes (Table 1) $[7,30]$. The physiological role of ErbB proteins was investigated in several mouse models. The absence of ErbB1 gene in mouse models was associated with respiratory, gastrointestinal, and skin problems [31-34] and the lack of ErbB2 gene in mouse models or the therapy against ErbB2 was accompanied by the heart failure [35-37].

Each family member has three main domains: the ligand binding domain, the transmembrane domain, and the kinase domain [38]. The crystal structure of the extracellular/ligand binding domain displayed ligand binding cleft only for three of the family members: ErbB1, ErbB3, and ErbB4, while ErbB2 has no ligand binding cleft [38-42]. For this reason ErbB2 is considered an orphan receptor since it has no ligand and it has a constitutive conformation which was shown to be similar to the activated form of the receptors $[8,43]$. The extracellular domain consists of four regions (I to IV) with different functions: I and III are responsible for ligand binding, and region II after ligand binding extends the dimerization arm, while the interaction between region II and IV maintains the extracellular domain in a tethered/inactive form [8].

The reported number of ErbB ligands increased to 11, namely, amphiregulin (AR), betacellulin (BCT), epidermal growth factor (EGF), epigen (EPG), epiregulin (EPR), heparin-binding EGF (HB-EGF), transforming growth factor alpha (TGF $\alpha$ ), neuregulin- (NRG-) 1 to neuregulin-4 $[5,7$, 38]. A family of proteases, disintegrin, and metalloproteases (ADAMs) are responsible for generation of ErbB family

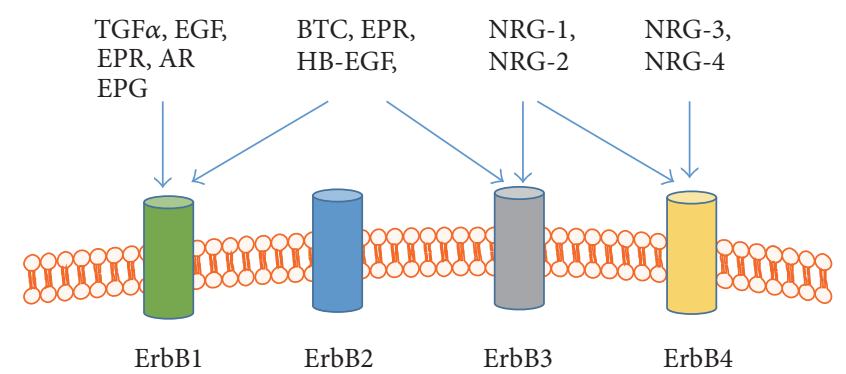

FIGURE 1: Schematic version of ligand binding for ErbB family. ErbB1 can bind AR, BCT, EGF, TGF $\alpha$, EPG, and EPR; ErbB3 can bind BCT, EPR, HB-EGF, NRG -1, and NRG-2, while ErbB4 can bind all four NRG $[5,7]$. AR, amphiregulin; BCT, betacellulin; EGF, epidermal growth factor; EPG, epigen; EPR, epiregulin; BH-EGF, heparin-binding EGF; TGF $\alpha$, transforming growth factor alpha; NRG, neuregulin.

ligands, which are released by ectodomain shedding from single-pass membrane precursor proteins $[44,45]$. The number of amino acid residues responsible for binding ErbB receptors varies from 53 amino acids in case of EGF to 359 amino acids in case of NRG-3 [7]. Up to now, a clear identification of which ligand binds to which ErbB homo- or heterodimer might be a complex task, since 11 ligands can bind 28 possible dimer combinations leading to more than 600 assortments [7]. However, a schematic version of ligand binding to ErbB receptors was depicted in Figure $1[5,7]$. After the ligand binding, homo- or heterodimerization of ErbB receptors takes place followed by activation of the intracellular kinase domain and by triggering of the numerous intracellular signaling pathways.

Two of the ErbB proteins have incomplete capacity to trigger the intracellular signaling: ErbB2 is an orphan receptor, while ErbB3 has no intrinsic kinase activity. However, the combination ErbB2-ErbB3 was shown to be the most mitogenic one compared to the other dimers of ErbB family $[5,8]$. The overexpression of ErbB2 protein in cancer cells made from this member of the family one of the preferred partners for heterodimerization; if there are not enough ErbB family partners on the surface of the cells, ErbB2 can form spontaneously homodimers [5]. Synchronized activation of phosphatidylinositol 3-kinase (PI3K)/Akt pathway, the mitogenactivated protein kinase (MAPK) pathway, phospholipase $\mathrm{C} \gamma$ $(\mathrm{PLC} \gamma)$, activation of Src kinase, signal transducer, and activator of transcription (STAT) pathway had been associated with increased cell division, survival, migration, differentiation, and inhibition of apoptosis [5]. Furthermore, crosstalking between ErbB signaling pathways and the estrogen 
receptors (ER), vascular endothelial growth factor (VEGF), insulin growth factor receptor (IGFR), and integrins pathways has been reported [46-50].

At the surface of the cancer cells, ErbB proteins are regularly overexpressed: at about two millions of EGFR in A-431 human epidermoid carcinoma cells and $10^{5}-10^{6}$ ErbB2 proteins in SK-BR-3 breast cancer cell line [51, 52]. The overexpression of ErbB proteins in different cancer types: lung (overexpression of EGFR in 60\% of non-small-cell lung cancer, NSCLC), breast (overexpression of ErbB2 in 20-30\% of breast cancer), gastric (overexpression of ErbB2 in 22\% of gastric cancer), or colorectal cancer (overexpression of EGFR in 25 to $82 \%$ of colorectal cancer) made them an attractive therapeutic target [27, 53-56].

The first molecules known to inhibit the activity of ErbB proteins (mainly EGFR and ErbB2) have been the antibodies, followed by small inhibitors of the TK domains [38]. One of the antibodies used to target EGFR had been the following: Erbitux (cetuximab) with antiproliferative activity and the ability to block the cell cycle in $G_{1}$ phase; until now Erbitux has been used in the therapy of colorectal cancer (CRC) and clinical trials are in progress for pancreatic cancer, head and neck squamous cell carcinoma, or NSCLC $[8,57]$. Matuzumab and panitumumab are two other monoclonal antibodies which can block EGFR activity; the antibodies are able to inhibit ligand-mediated activation followed by reduced EGFR signaling, cell cycle arrest, and reduced angiogenesis; clinical trials are in progress for CRC and NSCLC [8, 58, 59]. The activation of ErbB2 oncoprotein can be blocked by two monoclonal antibodies: trastuzumab (Herceptin) and pertuzumab (Omnitarg). The first one is able to bind to the IVth region of the extracellular domain of the protein and to trigger antibody-dependent cellular cytotoxicity (ADCC) by attracting the immune cells to the tumor site, while the second one recognizes the dimerization arm of ErbB2 protein being able to block the dimerization process $[5,7,8,38]$. Pertuzumab in combination with trastuzumab and docetaxel had the approval of the U.S. Food and Drug Administration (FDA) for the treatment of metastatic breast cancer [60] and for the use as neoadjuvant therapy in case of the patients with HER-2 positive breast cancer [61]. Another type of molecules able to block the activity of ErbB proteins is tyrosine kinase inhibitors (TKI): gefitinib (Iressa), erlotinib (Tarceva), and lapatinib; the first two target the tyrosine kinase domain of EGFR with activating mutation (L747-S752 deletion) and are approved for clinical applications in NSCLC [62-64]. A dual inhibitor of both EGFR and ErbB2 tyrosine kinases activity, lapatinib, had been applied mainly in metastatic breast cancer, since in other types of cancer it did not act as an effective inhibitor of the phosphorylation $[65,66]$.

The monoclonal antibodies and tyrosine kinase molecules showed improved response compared to nonspecific chemotherapy, but the positive responses have been limited to several months, being followed by diseases relapse. The causes of acquired resistance to synthesized molecules are various, for example, the acquisition of a new mutation in the molecular target (T790M EGFR) [67], masking the extracellular epitope of ErbB2 by hyaluronic acid [68], alternative pathways to support proliferation of the cancer cells (IGFR expression)
[69], or loss of one of the negative regulators of PI3K/Akt survival pathway (phosphatase and tensin homolog, PTEN) [70].

Since the malignant transformation is not reduced to only one type of event, a complex approach which involves synergic activity of several compounds might bring effective results. The administration of pertuzumab, trastuzumab, and docetaxel to the patients with metastatic breast cancer positive for HER-2 improved progression-free survival [71]. Moreover, with the aim of reducing the tumor size before the surgery, the neoadjuvant chemotherapy was administrated to the patients in early stages of breast cancer positive for HER-2 [72]. Commonly, the adjuvant therapies are accompanied by severe side effects (nausea, vomiting, myelosuppression, cardiotoxicity, etc.) and by multidrug resistance [72]. In the last time, more attention has been paid to the combination between anticancer drugs and natural compounds as potential therapeutic approaches [73]. Some of the advantages of using the natural compounds are related to their pleiotropic effects and to the ability of being well tolerated by the human body [74] However, most of the studies regarding the administration of natural compounds have been restricted to their preventive effects in cancer and clinical studies to support their therapeutic activity are missing $[74,75]$. A summary of the natural molecules known to inhibit the activity of ErbB proteins is presented in Table 2.

\section{Biological Properties of Dietary Phytochemicals}

Over the years dietary phytochemicals were proved to have numerous properties in chemoprevention of chronic diseases, including cancer [74]. For a better understanding about the beneficial properties of the dietary phytochemicals, many experiments, in vivo and in vitro, have been conducted. Dietary phytochemicals cover a large number of molecules and some were already shown to have biological activity in animal experiments and clinical trials. Their ability to interfere with abnormal proliferation of the cells, such as cancer progression, made them an attractive subject of study [74]. However, if natural compounds found in plants are not expected to treat cancer by themselves, a better understanding of their mechanisms of action can help us adopt the best strategy in cancer prevention or management. Phytochemicals have been classified according to their biological function, chemical structures, or the signaling pathway through which they act; regarding their chemical structure, phytochemicals are classified into polyphenols, alkaloids, carotenoids, and nitrogen compounds [76]. Polyphenols represent the substantial group of phytochemicals which showed many beneficial properties: antioxidant, anti-inflammatory, antitumor, neuroprotective, and antimicrobial $[75,77,78]$.

Clinical studies have shown increasing incidence in metastatic cancer due to overexpression of ErbB2 protein [27]. Moreover, the overexpression of ErbB proteins, mutations, or amplification of their genes has been associated with cancer progression $[7,8]$. Hence, potential dietary phytochemicals which downregulate ErbB proteins along with inhibiting the tyrosine kinase activity have been investigated. 
TABLE 2: Natural molecules which target ErbB proteins.

\begin{tabular}{|c|c|c|c|c|}
\hline Name & Target & Mechanism of action & $\begin{array}{l}\text { Clinical applications/ } \\
\text { in vitro or in vivo } \\
\text { experiments }\end{array}$ & References \\
\hline $\begin{array}{l}\text { Epigallocatechin-3- } \\
\text { gallate } \\
\text { (EGCG) }\end{array}$ & $\begin{array}{l}\text { EGFR } \\
\text { ErbB2 } \\
\text { ErbB3 } \\
\text { ErbB4 }\end{array}$ & $\begin{array}{l}\text { Inhibits the binding of EGF to EGFR } \\
\text { followed by inhibition of the signaling } \\
\text { pathways } \\
\text { Alters the lipid organization on the plasma } \\
\text { membrane (lipid rafts) } \\
\text { Promotes internalization of nonactivated } \\
\text { EGFR monomer } \\
\text { Reduces phosphorylation of EGFR }\end{array}$ & $\begin{array}{l}\text { Clinical trial HNSCC; } \\
\text { in vitro experiments: } \\
\text { epidermoid carcinoma cell } \\
\text { line (A- } 431 \text { ) }\end{array}$ & $\begin{array}{c}{[84,85,166,} \\
167]\end{array}$ \\
\hline Quercetin & $\begin{array}{l}\text { ErbB2 } \\
\text { ErbB3 }\end{array}$ & $\begin{array}{l}\text { Reduces the expression level of ErbB2 and } \\
\text { ErbB3 } \\
\text { Reduces phosphorylation of ErbB2 and } \\
\text { ErbB3 }\end{array}$ & $\begin{array}{l}\text { In vitro experiments: } \\
\text { prostate cancer cell lines }\end{array}$ & {$[168,169]$} \\
\hline Curcumin & $\begin{array}{l}\text { EGFR } \\
\text { ErbB2 }\end{array}$ & $\begin{array}{l}\text { Induces degradation of ErbB2 by } \\
\text { ubiquitination } \\
\text { Induces EGFR degradation }\end{array}$ & $\begin{array}{l}\text { In vitro experiments: EGFR } \\
\text { in several lung } \\
\text { adenocarcinoma cell lines; } \\
\text { ErbB2 transfected COS7 } \\
\text { cell line }\end{array}$ & {$[97,98,170]$} \\
\hline Resveratrol & ErbB2 & $\begin{array}{l}\text { Downregulates ErbB2 gene } \\
\text { Induces apoptosis }\end{array}$ & $\begin{array}{l}\text { In vitro experiments: } \\
\text { SK-BR- } 3 \text { breast cancer cell } \\
\text { lines }\end{array}$ & {$[171]$} \\
\hline Apigenin & $\begin{array}{l}\text { ErbB2 } \\
\text { ErbB3 }\end{array}$ & $\begin{array}{l}\text { Inhibits ErbB2 autophosphorylation and } \\
\text { transphosphorylation } \\
\text { Depletes ErbB2 by polyubiquitination } \\
\text { Inhibits the activity of ErbB2/ErbB3 } \\
\text { heterodimer }\end{array}$ & $\begin{array}{l}\text { In vitro experiments: } \\
\text { BT- } 474 \text {, SK-BR- } 3 \text { breast } \\
\text { cancer cell lines }\end{array}$ & [172] \\
\hline
\end{tabular}

HNSCC, squamous cell carcinoma of the head and neck.

3.1. EGCG. EGCG represents the most abundant polyphenolic catechin found in green tea [79]. Green tea, a popular beverage all over the world, possesses antioxidant properties, due, especially, to its high content in catechins. EGCG structure included eight hydroxyl groups and it was considered to possess anticarcinogenic effect due to its ability to induce apoptosis and to inhibit cell proliferation. The anticancer effect of EGCG was demonstrated through its ability to interfere with cell signaling pathways, NF-kB pathway, and cyclooxygenase-2 (COX-2) involved in cell transformation [80].

The anticarcinogenic properties of EGCG have been observed in multiple in vitro and in vivo studies. EGCG was proved to inhibit the tumor growth and the activation of ErbB1, ErbB2, and ErbB3 which are expressed in many different human cancer lines. Also, EGCG plays an important role in apoptosis and cell cycle arrest in tumor cells and in inhibiting the signaling pathways (MAPK, PI3K/AKT) and NF-kB activity [81]. Guo et al. demonstrated the effect of EGCG on NF639 cell line, which was obtained from a transgenic mouse, also called virus-HER-2/neu mouse. In this experiment EGCG inhibited the growth of mammary tumor cells in a dose-dependent manner; namely, $65 \%$ of the cells were inhibited by $40 \mu \mathrm{g} / \mathrm{mL}$ EGCG and $95 \%$ at $80 \mu \mathrm{g} / \mathrm{mL}$ EGCG. However, even after high doses of EGCG, $5 \%$ of colony formation showed resistance [82]. EGCG has been shown to have various anticancer effects in A431 epidermoid carcinoma cell line by blocking and inhibiting the tyrosine kinase activity of ErbB1 [83]. The activity of ErbB family members was decreased by EGCG in colon cancer cell lines, breast cancer, and human head and neck squamous cell carcinoma [81]. In the HT29 and SW80 colon cancer cell lines the treatments of EGCG also inhibited the ErbB2 and EGFR activity [84, 85]. Another two cell lines, BT-474 human breast cancer and YCU-H891 human head and neck squamous carcinoma cell lines, overexpressing ErbB2 were treated with EGCG to examine the inhibition of cell growth. After $72 \mathrm{~h}, \mathrm{EGCG}$ showed a greater inhibition of tumor growth in YCU-H891 line than in BT- 474 cells. Also, the effect of EGCG on ErbB2 phosphorylation in both cell lines was followed. The levels of phosphorylated ErbB2 (HER-2) were markedly decreased after $24 \mathrm{~h}$ at $10 \mu \mathrm{g} / \mathrm{mL}$ EGCG for YCU-H891 and $30 \mu \mathrm{g} / \mathrm{mL}$ EGCG for BT-474 [21]. In another study the inhibitory effect of EGCG on ErbB2 and ErbB3 overexpressing breast cancer cells was evaluated. Due to its ability to interfere with tyrosine-phosphorylation of ErbB2 and ErbB3, EGCG further inhibited downstream MAPK cascade, leading to the reduction in tumor growth [77]. In pancreatic cancer cells with ErbB protein expression [86] EGCG inhibited $\mathrm{PI} 3 \mathrm{~K} / \mathrm{Akt} / \mathrm{mTOR}$ pathway [87] and downregulated the activity of JAK/STAT3 pathway [88]. 
TABLE 3: Curcumin in animal studies.

\begin{tabular}{|c|c|c|c|}
\hline Animal model & Treatment & Main results & Ref \\
\hline $\begin{array}{l}\text { EGFR overexpressing A } 431 \\
\text { epidermoid carcinoma xenograft in } \\
\text { nude mice }\end{array}$ & $\begin{array}{l}0.5 \text { mg curcumin i.p. twice a day and } \\
1 \mathrm{~h} \text { visible light exposure after } \\
\text { treatment }\end{array}$ & $\begin{array}{l}\text { ErbB1 phosphorylation reduction; } \\
\text { decreased tumor growth through } \\
\text { proliferation reduction by } 70 \% \text { and } 4 \text {-fold } \\
\text { increased apoptosis }\end{array}$ & [101] \\
\hline $\begin{array}{l}\text { Erlotinib resistant ErbB1 mutant } \\
\text { NSCLC xenograft in nude mice }\end{array}$ & $\begin{array}{l}1 \mathrm{~g} / \mathrm{kg} \text { body weight curcumin, oral } \\
10 \mathrm{mg} / \mathrm{kg} \text { erlotinib }\end{array}$ & $\begin{array}{l}\text { Curcumin reduced ErbB1 expression and } \\
\text { induced apoptosis } \\
\text { Curcumin alone decreased tumor growth } \\
\text { and increased erlotinib effect on tumor } \\
\text { growth reduction }\end{array}$ & [102] \\
\hline $\begin{array}{l}\text { ErbB1 expressing LNCaP xenograft in } \\
\text { nude mice }\end{array}$ & $2 \%$ curcumin in diet & $\begin{array}{l}\text { Curcumin decreased tumor volume, } \\
\text { decreased mitosis, increased apoptosis, and } \\
\text { inhibited tumor angiogenesis }\end{array}$ & [103] \\
\hline $\begin{array}{l}\text { ErbB2 overexpressing BT- } 474 \text { breast } \\
\text { cancer xenograft in nude mice }\end{array}$ & $\begin{array}{l}45 \mathrm{mg} / \mathrm{kg} \text { curcumin i.p. twice per week } \\
\text { for } 4 \text { consecutive weeks }\end{array}$ & $\begin{array}{l}\text { Curcumin reduced the expression level of } \\
\text { ErbB2, p-Akt, p-MAPK, and NF- } \kappa \text { B; } \\
\text { curcumin decreased tumor volume by } 76.7 \%\end{array}$ & [20] \\
\hline
\end{tabular}

3.2. Curcumin. Curcumin (diferuloylmethane) is a nonflavonoid polyphenol found in turmeric derived from the roots of Curcuma longa plant. The yellow spice is widely used in Indian and in Ayurveda medicine as anti-inflammatory agent [89]. Besides curcumin, turmeric contains another three subclasses like demethoxycurcumin (curcumin II), bisdemethoxycurcumin (curcumin III), and cyclocurcumin [90]. Comparable to vitamin $\mathrm{C}$, curcumin has been shown to be a better antioxidant [91]. Curcumin was first isolated from turmeric in 1815 but there was no report about its therapeutic properties until 1970s. Since then, curcumin has been increasingly studied for its promising effects. Besides its antiinflammatory, anti-infectious, anticarcinogenic, and antioxidant properties, curcumin has been shown to interact with various extracellular and intracellular molecules involved in cancer progression having inhibitory effects on tumor cells [92-94]. The antiproliferative effects of curcumin manifest through the regulation of growth factors, protein kinases, cell receptors, various oncogenic proteins, and the induction of apoptosis and cell cycle arrest in cancer cells [95].

The anticarcinogenic effects of curcumin were tested in both in vitro and in vivo studies. Experimental studies with curcumin were carried out in human breast cancer cell lines, which expressed p $185^{\text {neu }}$, the oncoprotein encoded by ErbB2/ $\mathrm{Neu}$ gene. In vitro studies showed that $\mathrm{p} 185^{\text {neu }}$ autophosphorylation and transphosphorylation were inhibited by curcumin. Moreover, the depletion of $\mathrm{p} 185^{\text {neu }}$ with a curcumin IC50 (half maximal inhibitory concentration) of $6.5 \mu \mathrm{M}$ for the $24 \mathrm{~h}$ treatment was detected [96]. In another study using SK-BR-3 human breast cancer cell line and COS7 monkey fibroblasts transiently transfected with ErbB2, curcumin downregulated ErbB2 protein by ubiquitination through chaperone-dependent ubiquitin ligase, carboxyl terminus of HSP70-interacting protein (CHIP) [97]. When the effect of curcumin on the human malignant testicular cell line NTera2 was studied, the inhibition of ErbB2 expression and the reduced expression of activator protein-2 (AP) transcription factor were seen. Also in this study curcumin inhibited the tumor proliferation and induced apoptosis, through the inactivation of AP- $2 \gamma$ [98].
Beside the ability to inhibit the activity of EGFR, curcumin has been demonstrated to have pleiotropic biological effects which consist in the ability to modulate various signaling molecules like apoptotic proteins, proinflammatory transcription factors, such as NF-kB, cyclooxygenase-2, AP1, and signal transducer and activator of transcription (STAT) proteins $[99,100]$. Additionally, in SK-BR-3 and BT-474 breast cancer cell lines with ErbB3 overexpression curcumin inhibited the phosphorylation of Akt and MAPK pathways [20]. A summary of the mechanisms of action in case of EGCG and curcumin in preclinical studies is illustrated in Figure 2.

Curcumin has also been studied in animal ErbB expressing or overexpressing cancer models where it was very well tolerated and showed promising effects such as tumor size reduction, apoptosis inducement, and tumor prevention [101103]. Some of those studies are summarized in Table 3.

\section{Clinical Studies Involving EGCG and Curcumin}

Both EGCG and curcumin were studied in a number of phase I and II clinical studies involving patients with developed cancers or at high risk of developing malignancies. Those studies focused on establishing the best treatment regime for further studies and due to the small number of patients employed do not provide much information on the treatment efficacy.

EGCG studies recommended doses of up to $800 \mathrm{mg}$ oral EGCG daily. In those studies EGCG was administered in green tea catechins mixtures, as it was shown that such compositions potentiate the effect of the compound. EGCG was well tolerated in phase I and II clinical studies conducted with the most observed adverse effect being nausea found almost in all studies [104-108]. The largest study conducted included 1075 postmenopausal women at risk of breast cancer randomized in treatment ( $843 \pm 44 \mathrm{mg}$ EGCG daily) and placebo groups and was designed to establish if the toxicity of EGCG was low enough to justify its use as a chemoprevention compound. Due to the fact that percentage of adverse effects in the treatment group did not significantly vary from the one in the placebo group and those adverse effects were mild, the study 


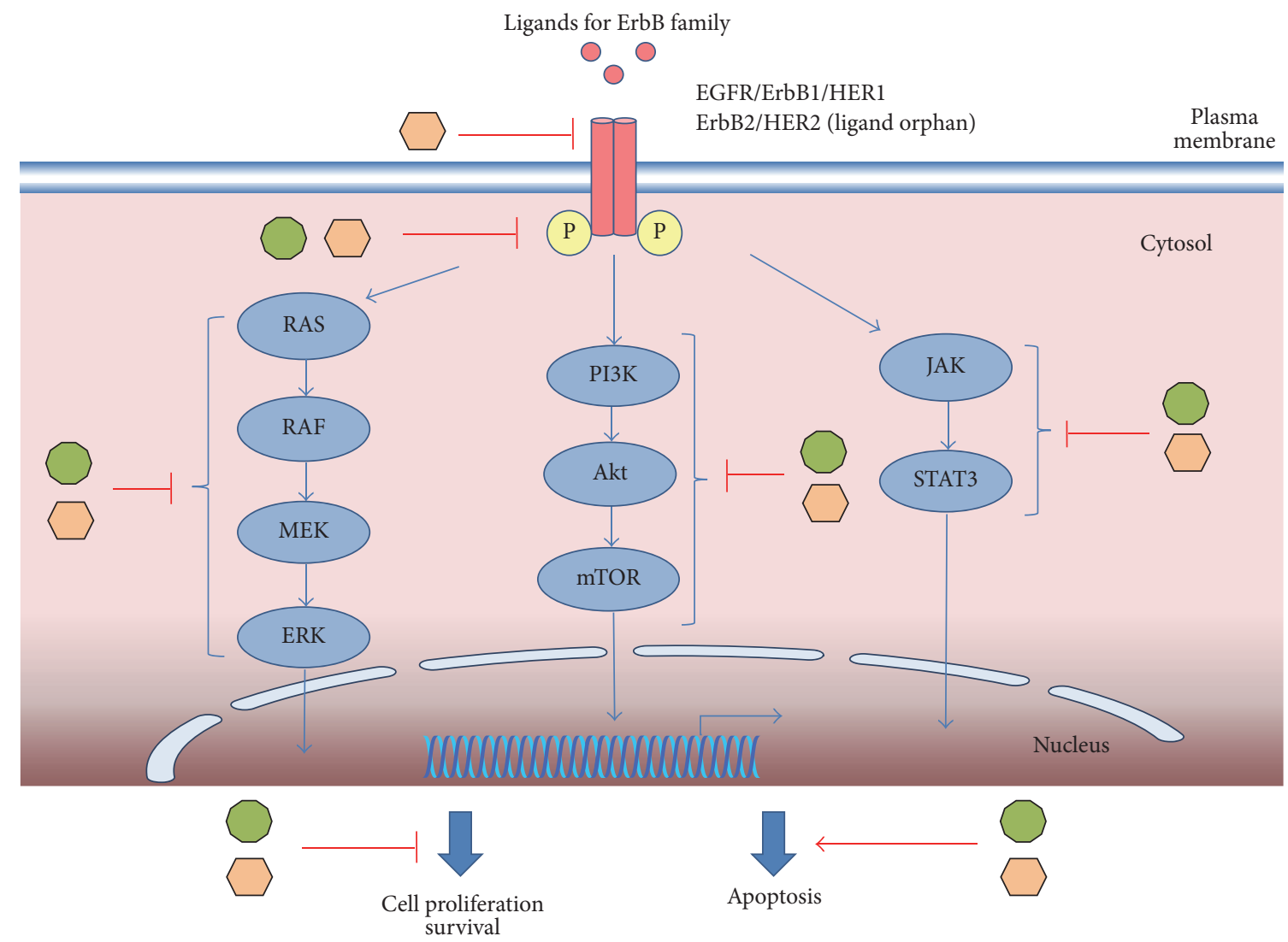

EGCG

Curcumin

FIGURE 2: Schematic molecular mechanisms of EGCG and curcumin activity. EGCG was shown to inhibit cell growth in NF639 breast cancer [82], in BT-74 breast cancer, and in YCU-H891 head and neck squamous carcinoma cell lines with ErbB2 overexpression [21]; downregulate the phosphorylation of ErbB proteins in A-4311 epidermoid carcinoma cell line [83], in colon cancer cells, in head and neck squamous cancer cells $[81,84,85]$, in BT-74 breast cancer, and in YCU-H891 head and neck squamous carcinoma cell lines [21]; and reduce the activity of downstream MAPK cascade [77], PI3K/Akt/mTOR pathway in pancreatic cancer cells [86, 87], and JAK/STAT3 pathway in pancreatic cancer cells with ErbB expression [88]. In cancer cells with ErbB protein expression, curcumin was able to inhibit the phosphorylation of ErbB2 in breast cancer cells [96], downregulate ErbB2 by ubiquitination in SK-BR3 breast cancer cells and COS-7 fibroblast transfected with ErbB2 [97], inhibit tumor proliferation and induce apoptosis in Ntera-2 human malignant testicular cell line [98], modulate the activity of STAT $[99,100]$, and inhibit the phosphorylation of Akt and MAPK in BT-474 and SK-BR-3 breast cancer cell lines [20].

concludes that "green tea and concentrated catechin extracts have potential for use as a safe, natural supplement for breast cancer risk reduction in healthy populations" [108].

Phase I clinical studies recommended oral doses of about $4 \mathrm{~g}$ curcumin, daily [109, 110] or $8 \mathrm{~g}$ curcumin daily [111], doses that were well tolerated, with only low levels of toxicity reflected in serum enzyme increase [109] and mild hematological toxicity such as neutropenia [111-113] and diarrhea $[109,110,113]$. In phase II clinical trials curcumin was also well tolerated when administered in combination with standard chemotherapeutic compounds such as docetaxel in advanced metastatic breast cancer [113] or gemcitabine in patients with advanced pancreatic cancer [112]. One study showed the colorectal cancer preventive action of curcumin, as the compound managed to reduce by $40 \%$ the number of aberrant crypt foci in high risk patients [110]. In summary, the main effects of EGCG and curcumin in clinical trials are presented in Table 4.

\section{Bioavailability}

5.1. EGCG Bioavailability. While epidemiological studies showed positive effects of green and black tea consumption such as reduced ovarian [114], biliary tract [115], or hepatocellular carcinoma [116] cancer risk, researchers working with EGCG have been puzzled by the lack of overlapping between in vivo achievable EGCG concentrations and the EGCG concentrations proved efficient in in vitro studies. Thus, in the past years there has been an increasing interest in finding EGCG formulations to increase the bioavailability of the compound (Table 5). 
TABLE 4: EGCG and curcumin in clinical trials.

\begin{tabular}{|c|c|c|c|c|c|}
\hline Phase & Treatment & Subjects & Main findings & Adverse effects & Ref \\
\hline \multicolumn{6}{|c|}{ EGCG } \\
\hline II & $\begin{array}{l}319.8 \pm 47.9 \mathrm{mg} \text { EGCG } \\
\text { oral daily from double } \\
\text { brewed green tea }\end{array}$ & $\begin{array}{l}16 \text { women in complete } \\
\text { remission after ovarian } \\
\text { cancer }\end{array}$ & $\begin{array}{l}5 \text { women free of recurrence at } \\
18 \text { months } \\
\text { Not enough evidence to } \\
\text { continue the study }\end{array}$ & $\begin{array}{l}\text { Nausea, abdominal pain, } \\
\text { vomiting; all adverse } \\
\text { effects were of grade } 1\end{array}$ & [104] \\
\hline II & $\begin{array}{l}1.3 \mathrm{~g} \text { green tea } \\
\text { polyphenols orally, daily, } \\
\text { of which } 800 \mathrm{mg} \text { EGCG } \\
\text { was used until } \\
\text { prostatectomy }\end{array}$ & $\begin{array}{l}26 \text { men with prostate } \\
\text { cancer }\end{array}$ & $\begin{array}{l}\text { EGCG treatment reduced } \\
\text { serum levels of HGF, VEGF, } \\
\text { IGF-BP3, IGF-I, and PSA }\end{array}$ & $\begin{array}{l}\text { No adverse effects on } \\
\text { liver function were } \\
\text { observed }\end{array}$ & [105] \\
\hline II & $\begin{array}{l}500,750, \text { and } \\
1000 \mathrm{mg} / \mathrm{m}^{2} \text { green tea } \\
\text { extracts orally three } \\
\text { times a day or placebo }\end{array}$ & $\begin{array}{l}41 \text { patients with oral } \\
\text { premalignant lesions }\end{array}$ & $\begin{array}{l}\text { Higher clinical response rate } \\
\text { and histologic response rate in } \\
\text { treatment group than in } \\
\text { placebo } \\
\text { No statistical difference in oral } \\
\text { cancer-free survival between } \\
\text { the groups }\end{array}$ & $\begin{array}{l}\text { Insomnia (due to } \\
\text { caffeine contained in the } \\
\text { formulation) } \\
\text { Headache } \\
\text { Nausea } \\
\text { Diarrhea }\end{array}$ & [106] \\
\hline $\mathrm{Ib}$ & $\begin{array}{l}200,400 \text {, and } 600 \mathrm{mg} \\
\text { poly E extract }(50-75 \% \\
\text { EGCG) or placebo }\end{array}$ & $\begin{array}{l}44 \text { patients with Barrett } \\
\text { esophagus }\end{array}$ & $\begin{array}{l}400 \mathrm{mg} \text { and } 600 \mathrm{mg} \text { treatment } \\
\text { resulted in organ accumulation } \\
\text { of EGCG in esophageal mucosa } \\
\text { No significant changes in } \\
\text { histological characteristics } \\
\text { between cohorts } \\
\text { One placebo subject developed } \\
\text { high-grade dysplasia }\end{array}$ & $\begin{array}{l}\text { Abdominal } \\
\text { pain/discomfort, } \\
\text { diarrhea, loss of energy, } \\
\text { nausea, upper } \\
\text { respiratory infection, } \\
\text { and ALT elevation }\end{array}$ & {$[107]$} \\
\hline \multicolumn{6}{|c|}{ Curcumin } \\
\hline I & $\begin{array}{l}0.45 \text { to } 3.6 \mathrm{~g} \text { oral } \\
\text { curcumin daily, for } 4 \\
\text { months }\end{array}$ & $\begin{array}{l}15 \text { patients with } \\
\text { advanced colorectal } \\
\text { cancer refractory to } \\
\text { treatment }\end{array}$ & $\begin{array}{l}\text { Dose-limiting toxicity was not } \\
\text { observed; stable disease after } 2 \\
\text { months of treatment ( } 2 \\
\text { patients); significant } \\
\text { improvement in quality of life } \\
\text { after } 1 \text { month of treatment (1 } \\
\text { patient) }\end{array}$ & $\begin{array}{l}\text { Serum alkaline } \\
\text { phosphatase rise, lactate } \\
\text { dehydrogenase rise, mild } \\
\text { to acute diarrhea } \\
\text { associated with longer } \\
\text { administration }\end{array}$ & [109] \\
\hline II & $\begin{array}{l}8 \mathrm{~g} \text { oral curcumin daily } \\
\text { until disease progression }\end{array}$ & $\begin{array}{l}25 \text { patients with } \\
\text { advanced pancreatic } \\
\text { adenocarcinoma }\end{array}$ & $\begin{array}{l}\text { One patient stable for }>18 \\
\text { months, another for } 8 \text { months, } \\
\text { and one patient with a brief, } \\
73 \% \text { reduction in tumor size }\end{array}$ & $\begin{array}{l}\text { No treatment related } \\
\text { toxic effects observed }\end{array}$ & [173] \\
\hline II & $\begin{array}{l}8 \mathrm{~g} \text { oral curcumin daily }+ \\
\text { gemcitabine } \\
1 \mathrm{~g} / \mathrm{m}^{2} \text { i.v. weekly } \times 3 \text { of } \\
4 \mathrm{wk}\end{array}$ & $\begin{array}{l}17 \text { patients with } \\
\text { advanced pancreatic } \\
\text { cancer }\end{array}$ & $\begin{array}{l}\text { Out of the } 11 \text { evaluable patients, } \\
9 \% \text { had partial response, } 36 \% \\
\text { had stable disease, and } 55 \% \text { had } \\
\text { tumor progression }\end{array}$ & $\begin{array}{l}\text { Abdominal fullness or } \\
\text { pain } \\
\text { Mild hematological } \\
\text { toxicity }\end{array}$ & [112] \\
\hline I/II & $\begin{array}{l}8 \mathrm{~g} \text { oral curcumin daily, } \\
\text { gemcitabine } \\
1 \mathrm{~g} / \mathrm{m}^{2} \text { i.v. days } 1 \text { and } 8, \\
\text { S- } 1 \text { orally for } 14 \\
\text { consecutive days every } 3 \\
\text { weeks }\end{array}$ & $\begin{array}{l}21 \text { patients with } \\
\text { gemcitabine resistant } \\
\text { pancreatic cancer }\end{array}$ & $\begin{array}{l}\text { Out of the } 18 \text { evaluable patients } \\
28 \% \text { showed stable disease }\end{array}$ & $\begin{array}{l}\text { Hematological toxicity, } \\
\text { fatigue (both probably } \\
\text { associated with } \\
\text { gemcitabine and not } \\
\text { curcumin) }\end{array}$ & {$[111]$} \\
\hline I & $\begin{array}{l}0.5 \text { to } 8 \mathrm{~g} \text { oral curcumin } \\
\text { daily }+75 \text { to } 100 \mathrm{mg} / \mathrm{m}^{2} \\
\text { docetaxel i.v. every } 3 \\
\text { weeks }\end{array}$ & $\begin{array}{l}14 \text { patients with } \\
\text { advanced and metastatic } \\
\text { breast cancer }\end{array}$ & $\begin{array}{l}5 \text { patients with partial response } \\
\text { to the treatment } \\
3 \text { patients with stable disease }\end{array}$ & $\begin{array}{l}\text { Diarrhea } \\
\text { Hematological toxicity } \\
\text { (neutropenia and } \\
\text { leucopenia) }\end{array}$ & {$[113]$} \\
\hline IIa & $\begin{array}{l}2 \mathrm{~g} \text { or } 4 \mathrm{~g} \text { oral curcumin, } \\
\text { daily for } 30 \text { days }\end{array}$ & $\begin{array}{l}41 \text { patients with }>8 \\
\text { aberrant crypt foci, } \\
\text { smokers }\end{array}$ & $\begin{array}{l}4 \mathrm{~g} \text { curcumin dose significantly } \\
\text { reduced the number of } \\
\text { premalignant lesions by } 40 \%\end{array}$ & $\begin{array}{l}\text { Toxicity (grade } 1 \text { to } 3 \text { ) or } \\
\text { diarrhea }\end{array}$ & [110] \\
\hline
\end{tabular}


TABLE 5: Bioavailability of EGCG.

\begin{tabular}{|c|c|c|c|c|c|c|}
\hline Species & Route & Dose & Plasma/tissue & $C_{\max }$ & AUC & Ref \\
\hline \multirow{2}{*}{ Rat } & i.v. & $10 \mathrm{mg} / \mathrm{kg}$ & Plasma & $4.7 \pm 0.9 \mu \mathrm{g} / \mathrm{mL}$ & $143.2 \pm 32.1 \mathrm{~min} \cdot \mu \mathrm{g} / \mathrm{mL}$ & \multirow[b]{2}{*}{ [117] } \\
\hline & i.g. & $75 \mathrm{mg} / \mathrm{kg}$ & Plasma & $19.8 \pm 3.5 \mathrm{ng} / \mathrm{mL}$ & $17.4 \pm 7.0 \mathrm{~min} \cdot \mu \mathrm{g} / \mathrm{mL}$ & \\
\hline \multirow{2}{*}{ Rat } & i.v. & $10 \mathrm{mg} / \mathrm{kg}$ & Plasma & $12269.5 \pm 2131.8 \mu \mathrm{g} / \mathrm{L}$ & $2772.2 \pm 479.9 \mathrm{~h} \cdot \mu \mathrm{g} / \mathrm{L}$ & \multirow{2}{*}{ [118] } \\
\hline & Oral & $100 \mathrm{mg} / \mathrm{kg}$ & Plasma & $11.0 \pm 5.9 \mu \mathrm{g} / \mathrm{L}$ & $39.6 \pm 14.2 \mathrm{~h} \cdot \mu \mathrm{g} / \mathrm{L}$ & \\
\hline \multirow{9}{*}{ Mice } & \multirow{8}{*}{ i.v. } & \multirow{8}{*}{$21.8 \mu \mathrm{mol} / \mathrm{kg}$} & Plasma & $13.6 \pm 2.0 \mu \mathrm{mol} / \mathrm{L}$ & $38.4 \pm 5.6 \mathrm{~min} \cdot \mu \mathrm{mol} / \mathrm{L}$ & \multirow{9}{*}{ [119] } \\
\hline & & & Prostate & $0.31 \pm 0.08 \mathrm{nmol} / \mathrm{g}$ & $56.1 \pm 16.0 \mathrm{~min} \cdot \mu \mathrm{mol} / \mathrm{L}$ & \\
\hline & & & Lung & $2.66 \pm 1.0 \mathrm{nmol} / \mathrm{g}$ & $91.0 \pm 37.3 \mathrm{~min} \cdot \mu \mathrm{mol} / \mathrm{L}$ & \\
\hline & & & Spleen & $0.83 \pm 0.22 \mathrm{nmol} / \mathrm{g}$ & $31.7 \pm 9.2 \mathrm{~min} \cdot \mu \mathrm{mol} / \mathrm{L}$ & \\
\hline & & & Liver & $3.56 \pm 0.8 \mathrm{nmol} / \mathrm{g}$ & $324.0 \pm 79.5 \mathrm{~min} \cdot \mu \mathrm{mol} / \mathrm{L}$ & \\
\hline & & & Kidney & $2.12 \pm 0.6 \mathrm{nmol} / \mathrm{g}$ & $55.0 \pm 17.0 \mathrm{~min} \cdot \mu \mathrm{mol} / \mathrm{L}$ & \\
\hline & & & Small intestine & $2.40 \pm 1.1 \mathrm{nmol} / \mathrm{g}$ & $114.0 \pm 51.8 \mathrm{~min} \cdot \mu \mathrm{mol} / \mathrm{L}$ & \\
\hline & & & Colon & $1.20 \pm 0.3 \mathrm{nmol} / \mathrm{g}$ & $325.3 \pm 88.7 \mathrm{~min} \cdot \mu \mathrm{mol} / \mathrm{L}$ & \\
\hline & i.g. & $163.8 \mu \mathrm{mol} / \mathrm{kg}$ & Plasma & $0.04 \pm 0.01 \mu \mathrm{mol} / \mathrm{L}$ & $45.6 \pm 13.5 \mathrm{~min} \cdot \mu \mathrm{mol} / \mathrm{L}$ & \\
\hline Human & Oral & $2 \mathrm{mg} / \mathrm{kg}$ & Plasma & 34.71 _ $22.87 \mathrm{ng} / \mathrm{mL}$ & $213.7 \pm 86.4 \mathrm{~h} \cdot \mathrm{ng} / \mathrm{mL}$ & [129] \\
\hline Human & Oral & $95 \mathrm{mg}$ & Plasma & NA & $857 \mathrm{~h} \cdot \mathrm{ng} / \mathrm{mL}$ & [131] \\
\hline \multirow{4}{*}{ Human } & Oral & $200 \mathrm{mg}$ & Plasma & $73.7 \pm 25.3 \mathrm{ng} / \mathrm{mL}$ & $22.5 \pm 7.3 \mathrm{~min} \cdot \mathrm{mg} / \mathrm{mL}$ & \multirow{4}{*}[130]{} \\
\hline & Oral & $400 \mathrm{mg}$ & Plasma & $111.8 \pm 98.6 \mathrm{ng} / \mathrm{mL}$ & $35.4 \pm 21.5 \mathrm{~min} \cdot \mathrm{mg} / \mathrm{mL}$ & \\
\hline & Oral & $600 \mathrm{mg}$ & Plasma & $169.1 \pm 139.6 \mathrm{ng} / \mathrm{mL}$ & $101.9 \pm 99.7 \mathrm{~min} \cdot \mathrm{mg} / \mathrm{mL}$ & \\
\hline & Oral & $800 \mathrm{mg}$ & Plasma & $438.5 \pm 284.4 \mathrm{ng} / \mathrm{mL}$ & $167.1 \pm 57.0 \mathrm{~min} \cdot \mathrm{mg} / \mathrm{mL}$ & \\
\hline
\end{tabular}

i.v.: intravenous; i.g.: intragastric; $C_{\max }$, maximum concentration; $\mathrm{AUC}$, area under the curve.

Absorption. EGCG absorption from decaffeinated green tea administered orally is only about $0.1 \%-0,15 \%$ in rats $[117,118]$ and about $12-26 \%$ in mice [119]. However, the EGCG absorption was shown to be modulated by the coadministration of EGCG with other dietary compounds such as piperine [120], sucrose and ascorbic acid [121], and genistein [122].

Area under the curve (AUC), an area of a concentrationtime plot showing when the drug start to be administrated till its concentration in plasma is very low, was used to compare the effect of EGCG under different applications. When administered intragastrically in mice, $6 \mathrm{~g} / \mathrm{kg}$ piperine increased AUC of total EGCG (coadministered at $75 \mathrm{~g} / \mathrm{kg}$ ) 1.2-fold and unconjugated EGCG 1.3-fold. The putative mechanism for this action was based on higher EGCG absorption through the inhibition of the intestinal glucuronidation of EGCG and, possibly, on gastrointestinal transit slowing [120]. The higher EGCG plasma bioavailability observed in sucrose and ascorbic acid formulation administered to rats may be caused by a longer gastric retention in the case of the higher viscosity formulation and a protective effect of ascorbic acid on EGCG oxidative degradation in the gastrointestinal tract [121].

Genistein was also found to increase EGCG bioavailability (about 1,5 -fold increase in AUC) and plasma half-life; however $0.01 \%$ EGCG in drinking fluids and $0.2 \%$ genistein in food supplementation led to higher tumorigenesis in male adenomatous polyposis coli APC ${ }^{\mathrm{min} /+}$ mice, limiting the use in vivo of such combinations [122]. EGCG was also shown to modulate its own bioavailability. When low doses, similar to those in green tea, were administered, a second dose of EGCG at 6 hours increases the EGCG available in blood and organs 4-6-fold [123]. On the other hand, AUC was 1.3-fold lower in pretreated mice (3.2 $\mathrm{mg} / \mathrm{g}$ EGCG for two weeks before the main dose) compared to nontreated mice which receive only the main dose (750 mg/kg EGCG) [124], showing a different modulation mechanism for higher EGCG doses after different term exposure to this flavonoid.

Metabolism. The EGCG low bioavailability is also regulated by multidrug resistance proteins (MRP) and high catechol-Omethyltransferase (COMT) methylation [125] ratios that lead to less active forms [118] like $4^{\prime \prime}$-O-methyl EGCG, the main methylation product $[126,127]$. Also, after absorption, EGCG shows pronounced plasma glucuronidation but, if administered intravenously (i.v.), most of EGCG found in tissues is unconjugated [119]. Glucuronidation occurs in a lesser extent in intestine and liver microsomes, about $12 \%$ in $3 \mathrm{~h} \mathrm{[128].}$

Distribution. A study using $\left[{ }^{3} \mathrm{H}\right]$-labeled EGCG showed wide distribution of the catechin in mouse tissues over a period of 24 hours after EGCG administration for one time, with concentrations in the liver, lung, pancreas, ovary, and mammary gland in the same order of magnitude as those found in plasma; the concentrations in the gastrointestinal tract were the highest, one or two orders of magnitude higher than those found in plasma, depending on the time-point analyzed [123].

Elimination. EGCG elimination occurs mainly through bile, as shown by a 4-fold or 2-fold higher AUC in the intestine compared to the kidney if decaffeinated green tea extract was administrated i.v. in rats [117] or mice, respectively [119].

In humans, EGCG reaches maximum plasma concentration after 1.3-1.6 hours at lower doses [129] and can reach up to 4 hours for doses of $800 \mathrm{mg}$ [130]. EGCG has 
an elimination half-life of about 3.4 hours, being cleared completely from plasma after 24 hours $[129,130]$. Similar to what was shown in animal studies, in healthy human subjects, EGCG bioavailability can be increased by other phytochemical compounds. EGCG formulated with low caffeine concentrations (EGCG to CAF ratio of 2:4) presented an AUC in blood 50\% higher than EGCG alone, but higher caffeine concentrations failed to prove the same effect [131].

In conclusion, the bioavailability of EGCG may be moderately increased by other different phytochemicals and by a proper dosing regimen.

5.2. Curcumin Bioavailability. Curcumin can be safely administered to humans in doses up to $12 \mathrm{~g}$ [132] and one dose escalation study recommended a dose of $6 \mathrm{~g}$ curcumin daily for one week, every three weeks [113]. Yet even when a $12 \mathrm{~g}$ dose was administered, curcumin serum levels only reached a maximum less of than $60 \mathrm{ng} / \mathrm{mL}$ at the 2-hour time-point [132].

Absorption. The main reason for the low bioavailability of curcumin is its insufficient water solubility, causing low absorption rates. Thus, a nanoparticle formulation strategy using particles formed from either low molecular weight $(5-15 \mathrm{kD})$ or high molecular weight $(50-75 \mathrm{kD})$ polylactic-co-glycolic acid found no differences between the two polymer sizes but a bioavailability 40 times greater than for free curcumin administration in rats [133].

Another method of increasing curcumin water solubility, and therefore its bioavailability, is complexing curcumin with phosphatidylcholine (PC). Thus, curcumin-PC complexes reach more than triple plasma concentrations and higher AUC at same concentrations than curcumin when it was administered in rats [134]. Other conjugation strategies have also been employed for increasing curcumin stability and solubility in water, such as combining it with hyaluronic acid [135], polyethylene glycol [136], or dendrimers [137], but have not been tested in vivo yet.

Curcumin water solubility was also increased successfully using a microemulsion vehicle containing a surfactant, oil, and cosurfactant and this increase in water solubility translated in an about 22 times higher bioavailability of curcumin in rats [138]. A 13-fold increase in bioavailability was observed also in the case of curcumin formulated as amorphous solid dispersion in a matrix consisting of hydroxypropyl methyl cellulose (HPMC), lecithin, and isomalt [139].

A new strategy to overcome curcumin bioavailability problems is the production of novel curcumin analogs. Such curcumin analogs developed for better water solubility can reach bioavailabilities of up to $60 \%$ when orally administered in mice [140]. Some curcumin analogs show improved anticancer effects in silico and in vitro [141], while others have already been tested in vivo and showed improvement in colorectal cancer [142] and glioma [143] survival or inhibited gastric carcinogenesis in mice. Such strategy may prove to find analogs not only with higher bioavailability, but also with improved biological activity. Different strategies for improving bioavailability can be the nanoformulated curcumin analogs which aim at a more specific distribution in tumor tissue [144].

Metabolism. Curcumin is conjugated in liver and intestine microsome to curcumin glucuronide and curcumin sulfate; hepatic and intestinal alcohol dehydrogenase reduces curcumin to hexahydrocurcumin [145]. There are differences in rat and human curcumin metabolisation, as intestinal microsomes produced 16 times greater curcumin glucuronide in humans than in rats, but hepatic glucuronidation was 3 times higher in rats [145], imposing a certain degree of caution when extrapolating bioavailability results obtained in rats to humans.

Curcumin bioavailability is further hindered by autoxidation processes at physiologic $\mathrm{pH}$. Thus curcumin oxidation forms a large number of intermediary metabolites such as quinone methide, peroxyl radical, endoperoxide, spiroepoxide, vinylether, and cyclopentadione [146] leading to the formation of bicyclopentadione [147].

Distribution. Curcumin and curcumin nanoparticles have different tissue distributions when administered intravenously. Curcumin nanoparticles present higher bioavailability than curcumin in liver, spleen, and lung than curcumin, while distribution to the heart, kidney, and brain is not greatly affected by nanoformulation, although slightly increased in brain and kidney [133].

Elimination. Though not entirely demonstrated, it has been theorized that curcumin conjugates are eliminated mainly through renal clearance [148] although curcumin conjugates were also found in feces [149].

In humans, nanoparticle curcumin formulations have already been tested on healthy volunteers and it was shown that they can reach plasma concentrations four times higher at the same time-point when administered in much lower doses of about $200 \mathrm{mg}$ [150] and show 27-fold higher bioavailability than curcumin powder [151]. Also, similar to EGCG, piperine was also found to increase curcumin bioavailability in humans through the inhibition of curcumin glucuronidation which might prove useful in curcumin-EGCG coadministration formulations $[152,153]$. Table 6 shows the bioavailability of curcumin in humans and in animal models.

To conclude, even if orally administrated curcumin shows a very little bioavailability, the bioavailability of the compound can be greatly increased using formulations that compensate for the low water solubility of the product and by using curcumin analogs with not only higher solubility but also higher stability.

\section{Synergistic Activity of EGCG and Curcumin}

Because of natural compounds low bioavailability, there is a need to find synergistic associations that might produce anticancer effects even at lower compound concentrations. Several possible combinations between EGCG or curcumin and anticancer drugs had been proven to potentiate the effects of the anticancer drugs in in vitro or in vivo studies [154-157]. At the same time the combination of EGCG or curcumin with 
TABLE 6: Bioavailability of curcumin.

\begin{tabular}{|c|c|c|c|c|c|c|}
\hline Species & Route & Dose & Plasma/tissue & $C_{\max }$ & AUC & Ref \\
\hline \multirow{6}{*}{ Rat } & \multirow{6}{*}{ i.v. } & \multirow{6}{*}{$25 \mathrm{mg} / \mathrm{kg}$} & Liver & NA & $9.06 \pm 1.55 \mathrm{~min} \cdot \mathrm{g} / \mathrm{mL}$ & \multirow{6}{*}{ [133] } \\
\hline & & & Heart & NA & $3.03 \pm 0.85 \mathrm{~min} \cdot \mathrm{g} / \mathrm{mL}$ & \\
\hline & & & Spleen & NA & $5.72 \pm 1.14 \mathrm{~min} \cdot \mathrm{g} / \mathrm{mL}$ & \\
\hline & & & Lung & NA & $8.98 \pm 1.82 \mathrm{~min} \cdot \mathrm{g} / \mathrm{mL}$ & \\
\hline & & & Kidney & NA & $12.0 \pm 0.88 \mathrm{~min} \cdot \mathrm{g} / \mathrm{mL}$ & \\
\hline & & & Brain & NA & $4.04 \pm 0.22 \mathrm{~min} \cdot \mathrm{g} / \mathrm{mL}$ & \\
\hline \multirow{2}{*}{ Rat } & \multirow{2}{*}{ Oral } & $50 \mathrm{mg} / \mathrm{kg}$ & Plasma & $13.0 \pm 5.8 \mathrm{ng} / \mathrm{mL}$ & $51.1 \pm 25 \mathrm{~min} \cdot \mathrm{g} / \mathrm{mL}$ & \multirow{2}{*}[151]{} \\
\hline & & $300 \mathrm{mg} / \mathrm{kg}$ & Plasma & $37.4 \pm 36.1 \mathrm{ng} / \mathrm{mL}$ & $134 \pm 114 \mathrm{~min} \cdot \mathrm{g} / \mathrm{mL}$ & \\
\hline Rat & Oral & $1 \mathrm{~g} / \mathrm{kg}$ & Plasma & $258.64 \mathrm{ng} / \mathrm{mL}$ & $2483.32 \mathrm{~h} \cdot \mathrm{ng} / \mathrm{mL}$ & {$[134]$} \\
\hline Human & Oral & $30 \mathrm{mg} / \mathrm{kg}$ & Plasma & $1.8 \pm 2.8 \mathrm{ng} / \mathrm{mL}$ & $4.1 \pm 7 \mathrm{~h} \cdot \mathrm{ng} / \mathrm{mL}$ & {$[151]$} \\
\hline \multirow{2}{*}{ Human } & \multirow{2}{*}{ Oral } & $10 \mathrm{~g}$ & Plasma & $50.5 \mathrm{ng} / \mathrm{mL}$ & NA & \multirow{2}{*}[132]{} \\
\hline & & $12 \mathrm{~g}$ & Plasma & $57.6 \mathrm{ng} / \mathrm{mL}$ & NA & \\
\hline
\end{tabular}

TABLE 7: Cell lines with ErbB protein expression.

\begin{tabular}{|c|c|c|c|}
\hline Cell line & Tissue/organ & ErbB proteins & Reference \\
\hline A2780 & Ovarian cancer cell line & EGFR: negative, ErbB2: positive, ErbB3: low positive, ErbB4: positive & {$[174]$} \\
\hline $\mathrm{Tu} 212$ & Hypopharyngeal cancer cell line & EGFR: positive & [158] \\
\hline A549 & Human lung carcinoma cell line & EGFR: positive & [158] \\
\hline MDA-MB-231 & Human breast cancer cell line & EGFR: positive, ErbB2: negative/positive & [175] \\
\hline MCF-7 & Human breast cancer cell line & EGFR, ErbB2: positive & {$[175]$} \\
\hline DLD-1 & Human colon cancer cell line & EGFR, ErbB2: positive & {$[176]$} \\
\hline HТ-29 & Human colon cancer cell line & EGFR, ErbB2: positive & {$[176]$} \\
\hline HCT 116 & Human colon cancer cell line & EGFR, ErbB2: positive & {$[176]$} \\
\hline TE-8 & Human esophageal cancer cell line & EGFR: positive & [177] \\
\hline SKGT-4 & Human esophageal cancer cell line & EGFR: positive & [178] \\
\hline HepG2 & Human hepatocarcinoma cell line & EGFR, ErbB2: positive & {$[179,180]$} \\
\hline CWR22R & Prostate cancer cell line & EGFR, ErbB2: positive & [181] \\
\hline Y79 & Human retinoblastoma cell line & ErbB2: positive & {$[182]$} \\
\hline
\end{tabular}

other natural compounds brought additional information about the ability of natural compounds to decrease cell growth, to induce apoptosis or induce cell cycle arrest [158160]. However a considerable lack of data was noticed regarding the clinical studies concerning the patients with ErbB positive tumors. Additionally, the lack of direct studies regarding ErbB proteins and synergistic activity of EGCG and curcumin was overcome by summarizing in Table 7 the malignant cell lines used for in vitro or in vivo experiments introduced in this chapter, according to the tissue origin of the cell line and the expression of ErbB proteins.

6.1. Synergistic Activity between Natural Compounds and Anticancer Drugs. EGCG was shown to synergistically interact with other drugs employed in cancer treatment and reduced cell viability, increased apoptosis, or inhibited cell growth had been observed [154-156]. Resistance to chemotherapy is an important factor of negative prognostic in oncology patients and therefore the synergy of the natural compounds may prove to play an important role in the treatment of chemoresistant tumors as they were shown to be effective in cisplatin resistant ovarian cancer cells $[154,155]$. There are data suggesting a better potentiation of the activity of the compound by sequential administration. In ovarian cancer cells, the effect of cisplatin or oxaliplatin was synergistically increased by curcumin or EGCG administration only when the natural compound was administered after cisplatin at 4 hours, but not before $[154,155]$. Curcumin analogs appear to maintain cisplatin potentiating effect, as proved on a cisplatin resistant carcinoma xenograft model [157]. Table 8 summarizes the synergistic activity of EGCG or curcumin and anticancer drugs both in in vitro and in vivo experiments in ErbB positive cells lines or xenograft tumors.

6.2. Synergistic Activity between Natural Compounds. In EGFR+ esophageal cancer lines curcumin and EGCG also greatly reduced $\mathrm{p}$-Erk1/2 expression and increase caspase-3 level [161]. The combination between EGCG and curcumin 
TABLE 8: The main effects of combination of EGCG or curcumin with anticancer drugs.

\begin{tabular}{|c|c|c|c|c|}
\hline Anticancer drug & Biological system/model & Doses & Main results & Ref \\
\hline \multicolumn{5}{|c|}{ EGCG: in vitro experiments } \\
\hline Oxaliplatin, cisplatin & $\begin{array}{l}\text { A } 2780 \text { and A2780R ovarian } \\
\text { cancer cell lines parental and } \\
\text { cisplatin resistant, respectively }\end{array}$ & $\begin{array}{l}\mathrm{ED}_{50}, \mathrm{ED}_{75}, \mathrm{ED}_{90}(\mathrm{ED}, \text { effective } \\
\text { dose })\end{array}$ & $\begin{array}{l}\text { Increased synergism at } \mathrm{ED}_{50} \text { after } \\
\text { the sequential administration of } \\
\text { the phytochemical, at } 4 \mathrm{~h} \text { after } \\
\text { oxaliplatin or cisplatin treatment } \\
\text { (increased growth inhibitory } \\
\text { effects) }\end{array}$ & {$[154,155]$} \\
\hline Oxaliplatin, cisplatin & $\begin{array}{l}\text { DLD-1, HT-29 human colorectal } \\
\text { adenocarcinoma cells }\end{array}$ & $\begin{array}{l}100 \mu \mathrm{M} \text { EGCG } \\
20 \mu \mathrm{M} \text { oxaliplatin or cisplatin }\end{array}$ & $\begin{array}{l}\text { Decreased cell proliferation, } \\
\text { induced autophagy }\end{array}$ & {$[156]$} \\
\hline \multicolumn{5}{|c|}{ Curcumin: in vitro experiments } \\
\hline $\begin{array}{l}\text { Carboplatin, etoposide, } \\
\text { vincristine }\end{array}$ & Y 79 retinoblastoma cells & $\begin{array}{l}5-10 \mu \mathrm{M} \text { curcumin } \\
5-10 \mu \mathrm{g} / \mathrm{mL} \text { carboplatin } \\
0.1-5 \mu \mathrm{g} / \mathrm{mL} \text { etoposide } \\
0.1-5 \mathrm{nM} \text { vincristine }\end{array}$ & $\begin{array}{l}\text { Increased apoptosis } \\
\text { Curcumin increased the } \\
\text { sensitivity of retinoblastoma cells } \\
\text { to carboplatin, etoposide, and } \\
\text { vincristine }\end{array}$ & {$[183]$} \\
\hline Oxaliplatin & $\begin{array}{l}\text { A } 2780 \text { and A2780R ovarian } \\
\text { cancer cell lines parental and } \\
\text { cisplatin resistant, respectively }\end{array}$ & $\begin{array}{l}\mathrm{ED}_{50}, \mathrm{ED}_{75}, \mathrm{ED}_{90}(\mathrm{ED}, \text { effective } \\
\text { dose })\end{array}$ & $\begin{array}{l}\text { Increased synergism at } \mathrm{ED}_{50} \text { after } \\
\text { the sequential administration of } \\
\text { the phytochemical, at } 4 \mathrm{~h} \text { after } \\
\text { oxaliplatin (increased growth } \\
\text { inhibitory effects) }\end{array}$ & {$[154,155]$} \\
\hline Cisplatin & $\begin{array}{l}\text { A2780R cisplatin resistant } \\
\text { human ovarian cancer cell line }\end{array}$ & $\begin{array}{l}1-10 \mu \mathrm{M} \text { curcumin analogs } \\
10 \mu \mathrm{g} / \mathrm{mL} \text { cisplatin }\end{array}$ & $\begin{array}{l}\text { Cotreatment increased } \\
\text { cytotoxicity (MTT assay), } \\
\text { induced G2/M arrest, increased } \\
\text { p21 and p53 levels, decreased } \\
\text { Bcl-2 and Bcl-XL levels, } \\
\text { increased caspase-9, caspase-3, } \\
\text { and caspase- } 7 \text { and PARP levels, } \\
\text { increased apoptosis, and reduced } \\
\text { STAT3 level }\end{array}$ & {$[157]$} \\
\hline
\end{tabular}

Curcumin: in vivo experiments

\begin{tabular}{|c|c|c|c|c|}
\hline \multicolumn{5}{|c|}{ Curcumin: in vivo experiments } \\
\hline Cisplatin & $\begin{array}{l}\text { Xenograft tumor in nude mice } \\
\text { with A2780R cells Cisplatin } \\
\text { resistant ovarian cancer cells }\end{array}$ & $\begin{array}{l}100 \text { ppm curcumin analogs in } \\
\text { feed } \\
4 \mathrm{mg} / \mathrm{kg} \text { cisplatin i.p. }\end{array}$ & $\begin{array}{l}\text { Cotreatment reduced the tumor } \\
\text { volume, decreased constitutive } \\
\text { activation of pSTAT3-Tyr705 and } \\
\text { pSTAT3-Ser727, decreased Bcl-2 } \\
\text { and Bcl-XL levels, and increased } \\
\text { PARP levels }\end{array}$ & {$[157]$} \\
\hline
\end{tabular}

administrated to breast cancer stem cell model reduced the number of CD44 positive cells and reduced the tumor-sphere formation reversing the stem cell phenotype [162]. In vitro studies found synergistic effects for either curcumin or EGCG when administered together with other dietary compounds. EGCG was found to exert synergistic apoptosis inducing effects with compounds such as resveratrol or gamma-tocotrienol in breast cancer cells [159], genistein and quercetin in prostate cancer cells [160], or luteolin in several head and neck cancer cell lines or lung cancer cells [158]. Curcumin was also shown to be potentiated by resveratrol in hepatocellular carcinoma cells [163]. In a xenograft model of nonsmall-cell lung cancer, $20 \mathrm{mg} / \mathrm{kg}$ curcumin and $100 \mathrm{mg} / \mathrm{kg}$ EGCG coadministration also reduced tumor size through cyclin D1 and cyclin B1 inhibition which led to cell cycle arrest in $\mathrm{G}_{2} / \mathrm{M}$ phase in [161]. The coadministration EGCG and curcumin significantly reduced tumor size in several xenograft nude mouse models $[161,164,165]$. However, little in vivo findings support the clinical use of such combinations yet. The synergy studies between EGCG and curcumin or EGCG/curcumin and other natural compounds have been summarized in Table 9.

A new mechanism described for both EGCG and curcumin which might explain in part the synergistic effects of the two compounds when administered together or with other therapeutic compounds is the modulation of multiple miRNA expression $[185,186]$. miRNA are small RNA fragments produced by noncoding DNA that have been found to play roles in many cancer-associated mechanisms such as cell differentiation, cell cycle, drug resistance, and metastasis [187]. EGCG was shown to decrease expression of oncogenic miR92, miR93, and miR106 while increasing tumor suppressors miR-7-1, miR-34a, and miR-99a in neuroblastoma cancer cells and curcumin was shown to increase expression of tumor suppressors miR-22, miR-34a, miR-101, miR141, miR429, miR-200b, miR-200c while downregulating 
TABLE 9: The main effects of combination between EGCG and curcumin or other natural compounds.

\begin{tabular}{|c|c|c|c|c|}
\hline Natural compound & Biological system/model & Doses & Main results & Ref \\
\hline \multicolumn{5}{|c|}{ EGCG: in vitro experiments } \\
\hline \multirow{3}{*}{ Curcumin } & $\begin{array}{l}\text { TE- } 8 \text { and SKGT- } 7 \text { esophageal } \\
\text { cancer cell lines }\end{array}$ & $\begin{array}{l}20-40 \mu \mathrm{M} \text { EGCG } \\
20-40 \mu \mathrm{M} \text { curcumin }\end{array}$ & $\begin{array}{l}\text { Reduced viability and } \\
\text { invasion ability, reduced } \\
\text { pErk1/2 and COX-2, } \\
\text { increased caspase- } 3 \text { level }\end{array}$ & {$[161]$} \\
\hline & $\begin{array}{l}\text { MDA-MB- } 231 \text { breast cancer } \\
\text { cell line }\end{array}$ & $\begin{array}{l}25 \mu \mathrm{M} \text { EGCG } \\
3 \mu \mathrm{M} \text { curcumin }\end{array}$ & $\begin{array}{l}\text { Increased synergistically } \\
\text { the cytotoxicity correlated } \\
\text { with } \mathrm{G} 2 / \mathrm{M} \text { phase arrest }\end{array}$ & {$[164$} \\
\hline & $\begin{array}{l}\text { MDA-MB-231 and MCF-7 } \\
\text { breast cancer cell lines } \\
\text { transfected with ErbB2 to } \\
\text { mimic breast cancer stem cells }\end{array}$ & $\begin{array}{l}10 \mu \mathrm{M} \text { EGCG } \\
10 \mu \mathrm{M} \text { curcumin }\end{array}$ & $\begin{array}{l}\text { Cotreatment reduced the } \\
\text { number of CD } 44 \text { positive } \\
\text { cells, reduced the } \\
\text { tumor-sphere formation, } \\
\text { and reduced the level of } \\
\text { pSTAT3 }\end{array}$ & {$[162]$} \\
\hline $\begin{array}{l}\text { Resveratrol, } \\
\gamma \text {-tocotrienol }\end{array}$ & MCF-7 breast cancer cell line & $\begin{array}{l}50 \mu \mathrm{M} \text { EGCG } \\
25 \mu \mathrm{M} \text { resveratrol } \\
10 \mu \mathrm{M} \gamma \text {-tocotrienol }\end{array}$ & $\begin{array}{l}\text { Inhibited cell proliferation } \\
\text { Additive effect when EGCG } \\
\text { was combined with } \\
\gamma \text {-tocotrienol in reducing } \\
\text { the levels of cyclin D1 and } \\
\text { Bcl-2 } \\
\text { Increased level of } \\
\text { antioxidant enzyme NQO1 } \\
\text { when all three } \\
\text { phytochemicals were used }\end{array}$ & [159] \\
\hline Genistein, quercetin & $\begin{array}{l}\text { CWR22Rv1 prostate cancer } \\
\text { cells }\end{array}$ & $\begin{array}{l}2.5 \mu \mathrm{M} \text { EGCG } \\
2.5 \mu \mathrm{M} \text { genistein } \\
2.5 \mu \mathrm{M} \text { quercetin }\end{array}$ & $\begin{array}{l}\text { Coadministration of EGCG } \\
\text { with genistein or quercetin } \\
\text { reduced the cell } \\
\text { proliferation and increased } \\
\text { cell death compared to each } \\
\text { treatment alone (the effects } \\
\text { were more pronounced in } \\
\text { case of combination of } \\
\text { EGCG with quercetin) }\end{array}$ & {$[160]$} \\
\hline Luteolin & $\begin{array}{l}\text { Several human head and neck } \\
\text { cancer cells from the primary } \\
\text { tumor and their lymph node } \\
\text { metastasis (Tu212, Tu686, } \\
686 \mathrm{LN} \text {, and 886LN) and } \\
\text { several lung cancer cell lines } \\
\text { (H292, A549, H460, H358, } \\
\text { H322, H1299, and Calu-1) }\end{array}$ & $\begin{array}{l}30 \mu \mathrm{M} \text { EGCG } \\
10 \mu \mathrm{M} \text { luteolin }\end{array}$ & $\begin{array}{l}\text { Synergistically increased } \\
\text { the level of apoptosis } \\
\text { (3-5-fold) compared to the } \\
\text { additive level } \\
\text { Mitochondrial } \\
\text { translocation of p53 after } \\
\text { the combined treatment }\end{array}$ & {$[158]$} \\
\hline
\end{tabular}

Curcumin: in vitro experiments

\begin{tabular}{|c|c|c|c|c|}
\hline Resveratrol & $\begin{array}{l}\text { Hepa 1-6 murine } \\
\text { hepatocarcinoma cell line }\end{array}$ & $\begin{array}{l}2.5-40 \mu \mathrm{M} \text { curcumin } \\
10-160 \mu \mathrm{M} \text { luteolin (fixed ratio } \\
1: 4)\end{array}$ & $\begin{array}{l}\text { were observed: increased } \\
\text { annexin V-propidium } \\
\text { iodide positive staining, } \\
\text { increased caspase- } 3 \text { activity, } \\
\text { increased the number of } \\
\text { the nuclei with apoptotic } \\
\text { morphology, increased } \\
\text { ROS production }\end{array}$ & [163] \\
\hline Silymarin & $\begin{array}{l}\text { DLD-1, LoVo, HCT116 human } \\
\text { colon cancer cells }\end{array}$ & $\begin{array}{l}0-100 \mu \mathrm{M} \text { curcumin } \\
0-100 \mu \mathrm{M} \text { silymarin }\end{array}$ & $\begin{array}{l}\text { Cotreatment induced: } \\
\text { increased antiproliferative } \\
\text { effects, increased apoptosis, } \\
\text { reduced cell survival }\end{array}$ & [184] \\
\hline
\end{tabular}

Synergistic effect of the cotreatment consisted in reduced cell survival. The following apoptosis effects were observed: increased annexin V-propidium iodide positive staining, increased caspase- 3 activity creased the number of nuclei with apoptotic ROS production

otreatment induced: effects, increased apoptosis, reduced cell survival 
TABLE 9: Continued.

\begin{tabular}{|c|c|c|c|c|}
\hline Natural compound & Biological system/model & Doses & Main results & Ref \\
\hline \multicolumn{5}{|c|}{ EGCG: in vivo experiments } \\
\hline \multirow{3}{*}{ Curcumin } & $\begin{array}{l}\text { Xenograft nude mouse model } \\
\text { with SKGT- } 4 \text { esophageal } \\
\text { cancer cells }\end{array}$ & $\begin{array}{l}50 \mu \mathrm{g} / \mathrm{kg} \text { EGCG } \\
50 \mu \mathrm{g} / \mathrm{kg} \text { curcumin }\end{array}$ & $\begin{array}{l}\text { Reduced tumor size after } \\
\text { cotreatment } \\
\text { Reduced expression of } \\
\text { Ki67, pERK, and } \\
\text { cyclooxygenase- } 2 \text { in } \\
\text { immunohistochemistry }\end{array}$ & {$[161]$} \\
\hline & $\begin{array}{l}\text { Xenograft nude mouse model } \\
\text { with A549 } \\
\text { non-small-cell lung cancer } \\
\text { cells (females) }\end{array}$ & $\begin{array}{l}100 \mathrm{mg} / \mathrm{kg} \text { EGCG } \\
20 \mathrm{mg} / \mathrm{kg} \text { curcumin }\end{array}$ & $\begin{array}{l}\text { Cotreatment protected the } \\
\text { mice against weight loss, } \\
\text { reduced the tumor growth, } \\
\text { reduced cyclin D1 and B2, } \\
\text { and reduced the level of the } \\
\text { proliferation marker Ki- } 67\end{array}$ & [165] \\
\hline & $\begin{array}{l}\text { Xenograft nude mouse model } \\
\text { with MDA-MB- } 231 \text { breast } \\
\text { cancer cells (females) }\end{array}$ & $\begin{array}{l}25 \mathrm{mg} / \mathrm{kg} \text { EGCG } \\
25 \mathrm{mg} / \mathrm{kg} \text { curcumin }\end{array}$ & $\begin{array}{l}\text { Cotreatment decreased the } \\
\text { tumor volume (by 49\%) } \\
\text { and the protein expression } \\
\text { level of VEGFR-1 (by 78\%), } \\
\text { but not the levels of EGFR } \\
\text { and Akt }\end{array}$ & [164] \\
\hline Luteolin & $\begin{array}{l}\text { Xenograft nude mice with } \\
\text { Tu212 hypopharyngeal cancer } \\
\text { cell line }\end{array}$ & $\begin{array}{l}125 \mathrm{mg} / \mathrm{kg} \text { EGCG } \\
10 \mathrm{mg} / \mathrm{kg} \text { luteolin }\end{array}$ & $\begin{array}{l}\text { Synergistically decreased in } \\
\text { Ki- } 67 \text { expression and } \\
\text { increased in TUNEL } \\
\text { positive cells and inhibition } \\
\text { of tumor volume }\end{array}$ & [158] \\
\hline
\end{tabular}

miR199a, in colorectal cancer cells or pancreatic cancer cells $[188,189]$.

\section{Conclusions}

Up to date the dietary phytochemicals have been used as chemopreventive agents or as potential therapeutic molecules in cancer models and their efficacy as therapeutic agents is missing, suggesting that the most promising results from in vitro or in vivo experiment might represent a start point for the future approaches in clinical studies. Moreover, the reduced bioavailability of the phytochemicals may represent future challenges for those working in the field. Better understanding of the molecular mechanisms about dietary phytochemicals in translational studies, from in vitro to clinical trials, will help us to identify future potential agents or combination of them for the chemoprevention of cancer.

\section{Competing Interests}

The authors declare that there is no conflict of interests regarding the publication of this paper.

\section{Authors' Contributions}

Alexandru Filippi and Oana-Alina Ciolac contributed equally to this work. All authors read and approved the final version of the manuscript.

\section{Acknowledgments}

This work was supported by the Romanian Ministry of Education and by the visiting professors fellowship program conducted by the Research Institute of the University of Bucharest.

\section{References}

[1] C. L. Arteaga and J. A. Engelman, "ERBB receptors: from oncogene discovery to basic science to mechanism-based cancer therapeutics," Cancer Cell, vol. 25, no. 3, pp. 282-303, 2014.

[2] H. Wu, Z. Cai, G. Lu et al., "Impact of c-erbB-2 protein on 5-year survival rate of gastric cancer patients after surgery: a cohort study and meta-analysis," Tumori Journal, 2015.

[3] S. Dębska-Szmich, R. Kusińska, U. Czernek et al., "Prognostic value of HER3, PTEN and p-HER2 expression in patients with HER2positive breast cancer," Postępy Higieny i Medycyny Doświadczalnej, vol. 69, pp. 586-597, 2015.

[4] A. Appert-Collin, P. Hubert, G. Crémel, and A. Bennasroune, "Role of ErbB receptors in cancer cell migration and invasion," Frontiers in Pharmacology, vol. 6, article 283, 2015.

[5] Y. Yarden and M. X. Sliwkowski, "Untangling the ErbB signalling network," Nature Reviews Molecular Cell Biology, vol. 2, no. 2, pp. 127-137, 2001.

[6] D. J. Arndt-Jovin, M. G. Botelho, and T. M. Jovin, "Structurefunction relationships of ErbB RTKs in the plasma membrane of living cells," Cold Spring Harbor Perspectives in Biology, vol. 6, no. 4, Article ID a008961, 2014. 
[7] R. Roskoski, “The ErbB/HER family of protein-tyrosine kinases and cancer," Pharmacological Research, vol. 79, pp. 34-74, 2014.

[8] N. E. Hynes and H. A. Lane, "ERBB receptors and cancer: the complexity of targeted inhibitors," Nature Reviews Cancer, vol. 5, no. 5, pp. 341-354, 2005.

[9] R. I. C. Russo, W. Béguelin, M. C. Díaz Flaqué et al., “Targeting ErbB-2 nuclear localization and function inhibits breast cancer growth and overcomes trastuzumab resistance," Oncogene, vol. 34, no. 26, pp. 3413-3428, 2015.

[10] B. F. Adem, N. R. A. Bastos, F. Dias, A. L. Teixeira, and R. Medeiros, "MiRNAs: mediators of ERBB family targeted therapy resistance," Pharmacogenomics, vol. 17, no. 10, pp. 11751187, 2016.

[11] R. Nahta, D. Yu, M.-C. Hung, G. N. Hortobagyi, and F. J. Esteva, "Mechanisms of disease: understanding resistance to HER2-targeted therapy in human breast cancer," Nature Clinical Practice Oncology, vol. 3, no. 5, pp. 269-280, 2006.

[12] Y. He, Y. Yue, X. Zheng, K. Zhang, S. Chen, and Z. Du, "Curcumin, inflammation, and chronic diseases: how are they linked?” Molecules, vol. 20, no. 5, pp. 9183-9213, 2015.

[13] M. K. Shanmugam, G. Rane, M. M. Kanchi et al., "The multifaceted role of curcumin in cancer prevention and treatment," Molecules, vol. 20, no. 2, pp. 2728-2769, 2015.

[14] S. Prasad and A. K. Tyagi, "Curcumin and its analogues: a potential natural compound against HIV infection and AIDS," Food and Function, vol. 6, no. 11, pp. 3412-3419, 2015.

[15] H. Tachibana, "Green tea polyphenol sensing," Proceedings of the Japan Academy, Series B, vol. 87, no. 3, pp. 66-80, 2011.

[16] P.-L. Liu, J.-T. Liu, H.-F. Kuo, I.-W. Chong, and C.-C. Hsieh, "Epigallocatechin gallate attenuates proliferation and oxidative stress in human vascular smooth muscle cells induced by interleukin-1 $\beta$ via heme oxygenase-1," Mediators of Inflammation, vol. 2014, Article ID 523684, 8 pages, 2014.

[17] F. Wu, H. Sun, T. Kluz, H. A. Clancy, K. Kiok, and M. Costa, "Epigallocatechin-3-gallate (EGCG) protects against chromateinduced toxicity in vitro," Toxicology and Applied Pharmacology, vol. 258, no. 2, pp. 166-175, 2012.

[18] J. Steinmann, J. Buer, T. Pietschmann, and E. Steinmann, "Antiinfective properties of epigallocatechin-3-gallate (EGCG), a component of green tea," British Journal of Pharmacology, vol. 168, no. 5, pp. 1059-1073, 2013.

[19] D. Chen, S. B. Wan, H. Yang, J. Yuan, T. H. Chan, and Q. P. Dou, "EGCG, green tea polyphenols and their synthetic analogs and prodrugs for human cancer prevention and treatment," Advances in Clinical Chemistry, vol. 53, pp. 155-177, 2011.

[20] H.-W. Lai, S.-Y. Chien, S.-J. Kuo et al., “The potential utility of curcumin in the treatment of HER-2-overexpressed breast cancer: an in vitro and in vivo comparison study with herceptin," Evidence-based Complementary and Alternative Medicine, vol. 2012, Article ID 486568, 12 pages, 2012.

[21] M. Masuda, M. Suzui, J. T. E. Lim, and I. B. Weinstein, "Epigallocatechin-3-gallate inhibits activation of HER-2/neu and downstream signaling pathways in human head and neck and breast carcinoma cells," Clinical Cancer Research, vol. 9, no. 9, pp. 3486-3491, 2003.

[22] M. Bassiri and M. L. Privalsky, "Mutagenesis of the avian erythroblastosis virus erbB coding region: an intact extracellular domain is not required for oncogenic transformation," Journal of Virology, vol. 59, no. 2, pp. 525-530, 1986.
[23] K. Khazaie, T. J. Dull, T. Graf et al., "Truncation of the human EGF receptor leads to differential transforming potentials in primary avian fibroblasts and erythroblasts," EMBO Journal, vol. 7, no. 10, pp. 3061-3071, 1988.

[24] S. Sundaresan, E. Penuel, and M. X. Sliwkowski, “The biology of human epidermal growth factor receptor 2," Current Oncology Reports, vol. 1, no. 1, pp. 16-22, 1999.

[25] A. L. Schechter, D. F. Stern, L. Vaidyanathan et al., "The neu oncogene: an erb-B-related gene encoding a 185,000-Mr tumour antigen," Nature, vol. 312, no. 5994, pp. 513-516, 1984.

[26] C. Shih, L. C. Padhy, M. Murray, and R. A. Weinberg, “Transforming genes of carcinomas and neuroblastomas introduced into mouse fibroblasts," Nature, vol. 290, no. 5803, pp. 261-264, 1981.

[27] D. J. Slamon, G. M. Clark, S. G. Wong, W. J. Levin, A. Ullrich, and W. L. McGuire, "Human breast cancer: correlation of relapse and survival with amplification of the HER-2/neu oncogene," Science, vol. 235, no. 4785, pp. 177-182, 1987.

[28] D. J. Slamon, W. Godolphin, L. A. Jones et al., "Studies of the HER-2/neu proto-oncogene in human breast and ovarian cancer," Science, vol. 244, no. 4905, pp. 707-712, 1989.

[29] M. J. Van de Vijver, J. L. Peterse, W. J. Mooi et al., "Neu-protein overexpression in breast cancer. Association with comedo-type ductal carcinoma in situ and limited prognostic value in Stage II breast cancer," New England Journal of Medicine, vol. 319, no. 19, pp. 1239-1245, 1988.

[30] A. L. Hughes, J. da Silva, and R. Friedman, "Ancient genome duplications did not structure the human Hox-bearing chromosomes," Genome Research, vol. 11, no. 5, pp. 771-780, 2001.

[31] P. J. Miettinen, J. E. Berger, J. Meneses et al., "Epithelial immaturity and multiorgan failure in mice lacking epidermal growth factor receptor," Nature, vol. 376, no. 6538, pp. 337-341, 1995.

[32] M. Sibilia and E. F. Wagner, "Strain-dependent epithelial defects in mice lacking the EGF receptor," Science, vol. 269, no. 5221, pp. 234-238, 1995.

[33] D. W. Threadgill, A. A. Dlugosz, L. A. Hansen et al., "Targeted disruption of mouse EGF receptor: effect of genetic background on mutant phenotype," Science, vol. 269, no. 5221, pp. 230-234, 1995.

[34] A. R. Tan, X. Yang, S. M. Hewitt et al., "Evaluation of biologic end points and pharmacokinetics in patients with metastatic breast cancer after treatment with erlotinib, an epidermal growth factor receptor tyrosine kinase inhibitor," Journal of Clinical Oncology, vol. 22, no. 15, pp. 3080-3090, 2004.

[35] K.-F. Lee, H. Simon, H. Chen, B. Bates, M.-C. Hung, and C. Hauser, "Requirement for neuregulin receptor erbB2 in neural and cardiac development," Nature, vol. 378, no. 6555, pp. 394398, 1995.

[36] S. A. Crone, Y.-Y. Zhao, L. Fan et al., "ErbB2 is essential in the prevention of dilated cardiomyopathy," Nature Medicine, vol. 8, no. 5, pp. 459-465, 2002.

[37] I. B. Fuchs, S. Landt, H. Bueler et al., "Analysis of HER2 and HER4 in human myocardium to clarify the cardiotoxicity of trastuzumab (Herceptin ${ }^{\mathrm{TM}}$ )," Breast Cancer Research and Treatment, vol. 82, no. 1, pp. 23-28, 2003.

[38] Y. Yarden and G. Pines, “The ERBB network: at last, cancer therapy meets systems biology," Nature Reviews: Cancer, vol. 12, no. 8, pp. 553-563, 2012. 
[39] A. W. Burgess, H.-S. Cho, C. Eigenbrot et al., "An open-andshut case? Recent insights into the activation of EGF/ErbB receptors," Molecular Cell, vol. 12, no. 3, pp. 541-552, 2003.

[40] H.-S. Cho and D. J. Leahy, "Structure of the extracellular region of HER3 reveals an interdomain tether," Science, vol. 297, no. 5585, pp. 1330-1333, 2002.

[41] T. P. J. Garrett, N. M. McKern, M. Lou et al., "The crystal structure of a truncated ErbB2 ectodomain reveals an active conformation, poised to interact with other ErbB receptors," Molecular Cell, vol. 11, no. 2, pp. 495-505, 2003.

[42] H.-S. Cho, K. Mason, K. X. Ramyar et al., "Structure of the extracellular region of HER2 alone and in complex with the Herceptin Fab," Nature, vol. 421, no. 6924, pp. 756-760, 2003.

[43] P. Nagy, A. Jenei, S. Damjanovich, T. M. Jovin, and J. SzÖllÔsi, "Complexity of signal transduction mediated by ErbB2: clues to the potential of receptor-targeted cancer therapy," Pathology and Oncology Research, vol. 5, no. 4, pp. 255-271, 1999.

[44] C. P. Blobel, "ADAMs: key components in egfr signalling and development," Nature Reviews: Molecular Cell Biology, vol. 6, no. 1, pp. 32-43, 2005.

[45] N. Rocks, G. Paulissen, M. El Hour et al., "Emerging roles of ADAM and ADAMTS metalloproteinases in cancer," Biochimie, vol. 90, no. 2, pp. 369-379, 2008.

[46] L. Yen, N. Benlimame, Z.-R. Nie et al., "Differential regulation of tumor angiogenesis by distinct ErbB homo- and heterodimers," Molecular Biology of the Cell, vol. 13, no. 11, pp. 4029-4044, 2002.

[47] Q. Jin and F. J. Esteva, "Cross-talk between the ErbB/HER family and the type I insulin-like growth factor receptor signaling pathway in breast cancer," Journal of Mammary Gland Biology and Neoplasia, vol. 13, no. 4, pp. 485-498, 2008.

[48] L. Pentassuglia and D. B. Sawyer, "ErbB/integrin signaling interactions in regulation of myocardial cell-cell and cell-matrix interactions," Biochimica et Biophysica Acta-Molecular Cell Research, vol. 1833, no. 4, pp. 909-916, 2013.

[49] R. Schiff, S. A. Massarweh, J. Shou et al., "Cross-talk between estrogen receptor and growth factor pathways as a molecular target for overcoming endocrine resistance," Clinical Cancer Research, vol. 10, no. 1, part 2, pp. 331S-336S, 2004.

[50] A. Prat and J. Baselga, "The role of hormonal therapy in the management of hormonal-receptor-positive breast cancer with co-expression of HER2," Nature Clinical Practice Oncology, vol. 5, no. 9, pp. 531-542, 2008.

[51] S. Cohen, R. A. Fava, and S. T. Sawyer, "Purification and characterization of epidermal growth factor receptor/protein kinase from normal mouse liver," Proceedings of the National Academy of Sciences of the United States of America, vol. 79, no. 20, pp. 6237-6241, 1982.

[52] M.-M. Mocanu, Z. Fazekas, M. Petrás et al., "Associations of ErbB2, $\beta 1$-integrin and lipid rafts on Herceptin (Trastuzumab) resistant and sensitive tumor cell lines," Cancer Letters, vol. 227, no. 2, pp. 201-212, 2005.

[53] R. S. Herbst, J. V. Heymach, and S. M. Lippman, "Lung cancer," The New England Journal of Medicine, vol. 359, no. 13, pp. 13671380, 2008.

[54] M. A. Owens, B. C. Horten, and M. M. Da Silva, "HER2 amplification ratios by fluorescence in situ hybridization and correlation with immunohistochemistry in a cohort of 6556 breast cancer tissues," Clinical Breast Cancer, vol. 5, no. 1, pp. 63-69, 2004.
[55] J. Lee and S.-H. I. Ou, "Towards the goal of personalized medicine in gastric cancer-time to move beyond HER2 inhibition. Part I: targeting receptor tyrosine kinase gene amplification," Discovery Medicine, vol. 15, no. 85, pp. 333-341, 2013.

[56] J. P. Spano, R. Fagard, J.-C. Soria, O. Rixe, D. Khayat, and G. Milano, "Epidermal growth factor receptor signaling in colorectal cancer: preclinical data and therapeutic perspectives," Annals of Oncology, vol. 16, no. 2, pp. 189-194, 2005.

[57] E. Aboud-pirak, E. Hurwitz, M. E. Pirak, F. Bellot, J. Schlessinger, and M. Sela, "Efficacy of antibodies to epidermal growth factor receptor against $\mathrm{KB}$ carcinoma in vitro and in nude mice," Journal of the National Cancer Institute, vol. 80, no. 20, pp. 1605-1611, 1988.

[58] C. Kollmannsberger, M. Schittenhelm, F. Honecker et al., "A phase I study of the humanized monoclonal antiepidermal growth factor receptor (EGFR) antibody EMD 72000 (matuzumab) in combination with paclitaxel in patients with EGFR-positive advanced non-small-cell lung cancer (NSCLC)," Annals of Oncology, vol. 17, no. 6, pp. 1007-1013, 2006.

[59] W. A. Messersmith and M. Hidalgo, "Panitumumab, a monoclonal anti-epidermal growth factor receptor antibody in colorectal cancer: another one or the one?" Clinical Cancer Research, vol. 13, no. 16, pp. 4664-4666, 2007.

[60] G. M. Blumenthal, N. S. Scher, P. Cortazar et al., "First FDA approval of dual anti-HER2 regimen: pertuzumab in combination with trastuzumab and docetaxel for HER2-positive metastatic breast cancer," Clinical Cancer Research, vol. 19, no. 18, pp. 4911-4916, 2013.

[61] L. Amiri-Kordestani, G. M. Blumenthal, Q. C. Xu et al., "FDA approval: ado-trastuzumab emtansine for the treatment of patients with HER2-positive metastatic breast cancer," Clinical Cancer Research, vol. 20, no. 17, pp. 4436-4441, 2014.

[62] T. J. Lynch, D. W. Bell, R. Sordella et al., "Activating mutations in the epidermal growth factor receptor underlying responsiveness of non-small-cell lung cancer to gefitinib," New England Journal of Medicine, vol. 350, no. 21, pp. 2129-2139, 2004.

[63] R. Rosell, E. Carcereny, R. Gervais et al., "Erlotinib versus standard chemotherapy as first-line treatment for European patients with advanced EGFR mutation-positive non-small-cell lung cancer (EURTAC): a multicentre, open-label, randomised phase 3 trial," The Lancet Oncology, vol. 13, no. 3, pp. 239-246, 2012.

[64] Y. Wang, G. Schmid-Bindert, and C. Zhou, "Erlotinib in the treatment of advanced non-small cell lung cancer: an update for clinicians," Therapeutic Advances in Medical Oncology, vol. 4, no. 1, pp. 19-29, 2012.

[65] P. J. Medina and S. Goodin, "Lapatinib: a dual inhibitor of human epidermal growth factor receptor tyrosine kinases," Clinical Therapeutics, vol. 30, no. 8, pp. 1426-1447, 2008.

[66] F. Montemurro, G. Valabrega, and M. Aglietta, "Lapatinib: a dual inhibitor of EGFR and HER2 tyrosine kinase activity," Expert Opinion on Biological Therapy, vol. 7, no. 2, pp. 257-268, 2007.

[67] S. Kobayashi, T. J. Boggon, T. Dayaram et al., "EGFR mutation and resistance of non-small-cell lung cancer to gefitinib," New England Journal of Medicine, vol. 352, no. 8, pp. 786-792, 2005.

[68] T. Váradi, T. Mersich, P. Auvinen et al., "Binding of trastuzumab to ErbB2 is inhibited by a high pericellular density of hyaluronan," Journal of Histochemistry and Cytochemistry, vol. 60, no. 8, pp. 567-575, 2012. 
[69] Y. Lu, X. Zi, Y. Zhao, D. Mascarenhas, and M. Pollak, "Insulin-like growth factor-I receptor signaling and resistance to trastuzumab (Herceptin)," Journal of the National Cancer Institute, vol. 93, no. 24, pp. 1852-1857, 2001.

[70] S. Venkateswarlu, D. M. Dawson, P. St Clair, A. Gupta, J. K. V. Willson, and M. G. Brattain, "Autocrine heregulin generates growth factor independence and blocks apoptosis in colon cancer cells," Oncogene, vol. 21, no. 1, pp. 78-86, 2002.

[71] S. M. Swain, J. Baselga, S.-B. Kim et al., "Pertuzumab, trastuzumab, and docetaxel in HER2-positive metastatic breast cancer," The New England Journal of Medicine, vol. 372, no. 8, pp. 724-734, 2015.

[72] L. De Mattos-Arruda, R. Shen, J. S. Reis-Filho, and J. Cortés, "Translating neoadjuvant therapy into survival benefits: one size does not fit all," Nature Reviews Clinical Oncology, vol. 13, no. 9, pp. 566-579, 2016.

[73] J. Cao, J. Han, H. Xiao, J. Qiao, and M. Han, "Effect of tea polyphenol compounds on anticancer drugs in terms of antitumor activity, toxicology, and pharmacokinetics," Nutrients, vol. 8, no. 12, article no. 762, 2016.

[74] Y.-J. Surh, "Cancer chemoprevention with dietary phytochemicals," Nature Reviews Cancer, vol. 3, no. 10, pp. 768-780, 2003.

[75] M.-M. Mocanu, P. Nagy, and J. Szöllosi, "Chemoprevention of breast cancer by dietary polyphenols," Molecules, vol. 20, no. 12, pp. 22578-22620, 2015.

[76] R. Kotecha, A. Takami, and J. L. Espinoza, "Dietary phytochemicals and cancer chemoprevention: a review of the clinical evidence," Oncotarget, vol. 7, no. 32, pp. 52517-52529, 2016.

[77] M. Fantini, M. Benvenuto, L. Masuelli et al., "In vitro and in vivo antitumoral effects of combinations of polyphenols, or polyphenols and anticancer drugs: perspectives on cancer treatment," International Journal of Molecular Sciences, vol. 16, no. 5, pp. 9236-9282, 2015.

[78] J. H. Lee, T. O. Khor, L. Shu, Z.-Y. Su, F. Fuentes, and A.N. T. Kong, "Dietary phytochemicals and cancer prevention: Nrf2 signaling, epigenetics, and cell death mechanisms in blocking cancer initiation and progression," Pharmacology and Therapeutics, vol. 137, no. 2, pp. 153-171, 2013.

[79] L. G. Xiong, Y. J. Chen, J. W. Tong et al., "Tea polyphenol epigallocatechin gallate inhibits Escherichia coli by increasing endogenous oxidative stress," Food Chemistry, vol. 217, pp. 196204, 2017.

[80] B. N. Singh, S. Shankar, and R. K. Srivastava, "Green tea catechin, epigallocatechin-3-gallate (EGCG): mechanisms, perspectives and clinical applications," Biochemical Pharmacology, vol. 82, no. 12, pp. 1807-1821, 2011.

[81] M. Shimizu, Y. Shirakami, and H. Moriwaki, "Targeting receptor tyrosine kinases for chemoprevention by green tea catechin, EGCG," International Journal of Molecular Sciences, vol. 9, no. 6, pp. 1034-1049, 2008.

[82] S. Guo, J. Lu, A. Subramanian, and G. E. Sonenshein, "Microarray-assisted pathway analysis identifies mitogenactivated protein kinase signaling as a mediator of resistance to the green tea polyphenol epigallocatechin 3-gallate in Her2/neu-overexpressing breast cancer cells," Cancer Research, vol. 66, no. 10, pp. 5322-5329, 2006.

[83] Y.-C. Liang, S.-Y. Lin-shiau, C.-F. Chen, and J.-K. Lin, "Suppression of extracellular signals and cell proliferation through EGF receptor binding by (-)-epigallocatechin gallate in human A431 epidermoid carcinoma cells," Journal of Cellular Biochemistry, vol. 67 , no. 1, pp. 55-65, 1997.
[84] S. Adachi, T. Nagao, H. I. Ingolfsson et al., "The inhibitory effect of (-)-epigallocatechin gallate on activation of the epidermal growth factor receptor is associated with altered lipid order in HT29 colon cancer cells," Cancer Research, vol. 67, no. 13, pp. 6493-6501, 2007.

[85] S. Adachi, M. Shimizu, Y. Shirakami et al., “(-)-Epigallocatechin gallate downregulates EGF receptor via phosphorylation at Ser1046/1047 by p38 MAPK in colon cancer cells," Carcinogenesis, vol. 30, no. 9, pp. 1544-1552, 2009.

[86] M. Komoto, B. Nakata, R. Amano et al., "HER2 overexpression correlates with survival after curative resection of pancreatic cancer," Cancer Science, vol. 100, no. 7, pp. 1243-1247, 2009.

[87] S. Liu, X.-J. Wang, Y. Liu, and Y.-F. Cui, "PI3K/AKT/mTOR signaling is involved in (-)-epigallocatechin-3-gallate-induced apoptosis of human pancreatic carcinoma cells," American Journal of Chinese Medicine, vol. 41, no. 3, pp. 629-642, 2013.

[88] S.-N. Tang, J. Fu, S. Shankar, and R. K. Srivastava, "EGCG enhances the therapeutic potential of gemcitabine and CP690550 by inhibiting STAT3 signaling pathway in human pancreatic cancer," PLoS ONE, vol. 7, no. 2, Article ID e31067, 2012.

[89] J. S. Jurenka, "Anti-inflammatory properties of curcumin, a major constituent of Curcuma longa: a review of preclinical and clinical research," Alternative Medicine Review, vol. 14, no. 2, pp. 141-153, 2009.

[90] J. Ravindran, S. Prasad, and B. B. Aggarwal, "Curcumin and cancer cells: how many ways can curry kill tumor cells selectively?" AAPS Journal, vol. 11, no. 3, pp. 495-510, 2009.

[91] R. K. Maheshwari, A. K. Singh, J. Gaddipati, and R. C. Srimal, "Multiple biological activities of curcumin: a short review," Life Sciences, vol. 78, no. 18, pp. 2081-2087, 2006.

[92] J. G. Devassy, I. D. Nwachukwu, and P. J. H. Jones, "Curcumin and cancer: barriers to obtaining a health claim," Nutrition Reviews, vol. 73, no. 3, pp. 155-165, 2015.

[93] A. H. Rahmani, M. A. Al Zohairy, S. M. Aly, and M. A. Khan, "Curcumin: a potential candidate in prevention of cancer via modulation of molecular pathways," BioMed Research International, vol. 2014, Article ID 761608, 15 pages, 2014.

[94] A. B. Kunnumakkara, P. Anand, and B. B. Aggarwal, "Curcumin inhibits proliferation, invasion, angiogenesis and metastasis of different cancers through interaction with multiple cell signaling proteins," Cancer Letters, vol. 269, no. 2, pp. 199-225, 2008.

[95] K. I. Priyadarsini, "The chemistry of curcumin: from extraction to therapeutic agent," Molecules, vol. 19, no. 12, pp. 20091-20112, 2014.

[96] R. L. Hong, W. H. Spohn, and M. C. Hung, "Curcumin inhibits tyrosine kinase activity of $185_{\text {neu }}$ and also depletes $\mathrm{p} 185_{\text {neu }}$ " Clinical Cancer Research, vol. 5, no. 7, pp. 1884-1891, 1999.

[97] Y. Jung, W. Xu, H. Kim, N. Ha, and L. Neckers, "Curcumininduced degradation of ErbB2: a role for the E3 ubiquitin ligase CHIP and the Michael reaction acceptor activity of curcumin," Biochimica et Biophysica Acta - Molecular Cell Research, vol. 1773, no. 3, pp. 383-390, 2007.

[98] C. Zhou, X.-M. Zhao, X.-F. Li et al., "Curcumin inhibits AP-2 $\gamma$ induced apoptosis in the human malignant testicular germ cells in vitro," Acta Pharmacologica Sinica, vol. 34, no. 9, pp. 11921200, 2013.

[99] S. C. Gupta, S. Patchva, W. Koh, and B. B. Aggarwal, "Discovery of curcumin, a component of golden spice, and its miraculous 
biological activities," Clinical and Experimental Pharmacology and Physiology, vol. 39, no. 3, pp. 283-299, 2012.

[100] S. C. Gupta, S. Patchva, and B. B. Aggarwal, "Therapeutic roles of curcumin: lessons learned from clinical trials," AAPS Journal, vol. 15, no. 1, pp. 195-218, 2013.

[101] J. Dujic, S. Kippenberger, A. Ramirez-Bosca et al., "Curcumin in combination with visible light inhibits tumor growth in a xenograft tumor model," International Journal of Cancer, vol. 124, no. 6, pp. 1422-1428, 2009.

[102] S. Li, Z. Liu, F. Zhu et al., "Curcumin lowers erlotinib resistance in non-small cell lung carcinoma cells with mutated EGF receptor," Oncology Research, vol. 21, no. 3, pp. 137-144, 2013.

[103] T. Dorai, Y.-C. Cao, B. Dorai, R. Buttyan, and A. E. Katz, "Therapeutic potential of curcumin in human prostate cancer. III. Curcumin inhibits proliferation, induces apoptosis, and inhibits angiogenesis of LNCaP prostate cancer cells in vivo," Prostate, vol. 47, no. 4, pp. 293-303, 2001.

[104] D. Trudel, D. P. Labbé, M. Araya-Farias et al., "A two-stage, single-arm, phase II study of EGCG-enriched green tea drink as a maintenance therapy in women with advanced stage ovarian cancer," Gynecologic Oncology, vol. 131, no. 2, pp. 357-361, 2013.

[105] J. McLarty, R. L. H. Bigelow, M. Smith, D. Elmajian, M. Ankem, and J. A. Cardelli, "Tea polyphenols decrease serum levels of prostate-specific antigen, hepatocyte growth factor, and vascular endothelial growth factor in prostate cancer patients and inhibit production of hepatocyte growth factor and vascular endothelial growth factor in vitro," Cancer Prevention Research, vol. 2, no. 7, pp. 673-682, 2009.

[106] A. S. Tsao, D. Liu, J. Martin et al., "Phase II randomized, placebo-controlled trial of green tea extract in patients with high-risk oral premalignant lesions," Cancer Prevention Research, vol. 2, no. 11, pp. 931-941, 2009.

[107] A. K. Joe, F. Schnoll-Sussman, R. S. Bresalier et al., "Phase Ib randomized, double-blinded, placebo-controlled, dose escalation study of polyphenon $\mathrm{E}$ in patients with Barrett's Esophagus," Cancer Prevention Research, vol. 8, no. 12, pp. 1131-1137, 2015.

[108] A. M. Dostal, H. Samavat, S. Bedell et al., "The safety of green tea extract supplementation in postmenopausal women at risk for breast cancer: results of the Minnesota Green Tea Trial," Food and Chemical Toxicology, vol. 83, pp. 26-35, 2015.

[109] R. A. Sharma, S. A. Euden, S. L. Platton et al., "Phase I clinical trial of oral curcumin: biomarkers of systemic activity and compliance," Clinical Cancer Research, vol. 10, no. 20, pp. 68476854, 2004.

[110] R. E. Carroll, R. V. Benya, D. K. Turgeon et al., "Phase IIa clinical trial of curcumin for the prevention of colorectal neoplasia," Cancer Prevention Research, vol. 4, no. 3, pp. 354-364, 2011.

[111] M. Kanai, K. Yoshimura, M. Asada et al., "A phase I/II study of gemcitabine-based chemotherapy plus curcumin for patients with gemcitabine-resistant pancreatic cancer," Cancer Chemotherapy and Pharmacology, vol. 68, no. 1, pp. 157-164, 2011.

[112] R. Epelbaum, M. Schaffer, B. Vizel, V. Badmaev, and G. BarSela, "Curcumin and gemcitabine in patients with advanced pancreatic cancer," Nutrition and Cancer, vol. 62, no. 8, pp. 11371141, 2010.

[113] M. Bayet-Robert, F. Kwiatkowski, M. Leheurteur et al., "Phase I dose escalation trial of docetaxel plus curcumin in patients with advanced and metastatic breast cancer," Cancer Biology and Therapy, vol. 9, no. 1, pp. 8-14, 2010.
[114] A. H. Lee, D. Su, M. Pasalich, and C. W. Binns, "Tea consumption reduces ovarian cancer risk," Cancer Epidemiology, vol. 37, no. 1, pp. 54-59, 2013.

[115] T. Makiuchi, T. Sobue, T. Kitamura et al., "Association between green tea/coffee consumption and biliary tract cancer: a population-based cohort study in Japan," Cancer Science, vol. 107, no. 1, pp. 76-83, 2016.

[116] C. Bamia, P. Lagiou, M. Jenab et al., "Coffee, tea and decaffeinated coffee in relation to hepatocellular carcinoma in a European population: multicentre, prospective cohort study," International Journal of Cancer, vol. 136, no. 8, pp. 1899-1908, 2015.

[117] L. Chen, M.-J. Lee, H. Li, and C. S. Yang, "Absorption, distribution, and elimination of tea polyphenols in rats," Drug Metabolism and Disposition, vol. 25, no. 9, pp. 1045-1050, 1997.

[118] Y. Oritani, Y. Setoguchi, R. Ito, H. Maruki-Uchida, T. Ichiyanagi, and T. Ito, "Comparison of (-)-epigallocatechin-3-O-gallate (EGCG) and O-methyl EGCG bioavailability in rats," Biological and Pharmaceutical Bulletin, vol. 36, no. 10, pp. 1577-1582, 2013.

[119] J. D. Lambert, M.-J. Lee, H. Lu et al., "Epigallocatechin-3gallate is absorbed but extensively glucuronidated following oral administration to mice," The Journal of Nutrition, vol. 133, no. 12, pp. 4172-4177, 2003.

[120] J. D. Lambert, J. Hong, D. H. Kim, V. M. Mishin, and C. S. Yang, "Piperine enhances the bioavailability of the tea polyphenol ()-epigallocatechin-3-gallate in mice," Journal of Nutrition, vol. 134, no. 8, pp. 1948-1952, 2004.

[121] C. M. Peters, R. J. Green, E. M. Janle, and M. G. Ferruzzi, "Formulation with ascorbic acid and sucrose modulates catechin bioavailability from green tea," Food Research International, vol. 43, no. 1, pp. 95-102, 2010.

[122] J. D. Lambert, S.-J. Kwon, J. Ju et al., "Effect of genistein on the bioavailability and intestinal cancer chemopreventive activity of (-)-epigallocatechin-3-gallate," Carcinogenesis, vol. 29, no. 10, pp. 2019-2024, 2008.

[123] M. Suganuma, S. Okabe, M. Oniyama, Y. Tada, H. Ito, and H. Fujiki, "Wide distribution of [3H](-)-epigallocatechin gallate, a cancer preventive tea polyphenol, in mouse tissue," Carcinogenesis, vol. 19, no. 10, pp. 1771-1776, 1998.

[124] K. D. James, S. C. Forester, and J. D. Lambert, "Dietary pretreatment with green tea polyphenol, (-)-epigallocatechin-3-gallate reduces the bioavailability and hepatotoxicity of subsequent oral bolus doses of (-)-epigallocatechin-3-gallate," Food and Chemical Toxicology, vol. 76, pp. 103-108, 2015.

[125] K. Landis-Piwowar, D. Chen, T. H. Chan, and Q. P. Dou, "Inhibition of catechol-O-methyltransferase activity in human breast cancer cells enhances the biological effect of the green tea polyphenol (-)-EGCG," Oncology Reports, vol. 24, no. 2, pp. 563-569, 2010.

[126] P. Wang, D. Heber, and S. M. Henning, "Quercetin increased bioavailability and decreased methylation of green tea polyphenols in vitro and in vivo," Food and Function, vol. 3, no. 6, pp. 635-642, 2012.

[127] P. Wang, W. J. Aronson, M. Huang et al., “Green tea polyphenols and metabolites in prostatectomy tissue: implications for cancer prevention," Cancer Prevention Research, vol. 3, no. 8, pp. 985993, 2010.

[128] V. Crespy, N. Nancoz, M. Oliveira, J. Hau, M.-C. CourtetCompondu, and G. Williamson, "Glucuronidation of the 
green tea catechins, (-)-epigallocatechin-3-gallate and (-)epicatechin-3-gallate, by rat hepatic and intestinal microsomes," Free Radical Research, vol. 38, no. 9, pp. 1025-1031, 2004.

[129] M.-J. Lee, P. Maliakal, L. Chen et al., "Pharmacokinetics of tea catechins after ingestion of green tea and (-)-epigallocatechin3-gallate by humans: formation of different metabolites and individual variability," Cancer Epidemiology Biomarkers and Prevention, vol. 11, no. 10, pp. 1025-1032, 2002.

[130] H.-H. S. Chow, Y. Cai, D. S. Alberts et al., "Phase I pharmacokinetic study of tea polyphenols following single-dose administration of epigallocatechin gallate and Polyphenon E," Cancer Epidemiology Biomarkers and Prevention, vol. 10, no. 1, pp. 53-58, 2001.

[131] K. Nakagawa, K. Nakayama, M. Nakamura et al., "Effects of coadministration of tea epigallocatechin-3-gallate (EGCG) and caffeine on absorption and metabolism of EGCG in humans," Bioscience, Biotechnology and Biochemistry, vol. 73, no. 9, pp. 2014-2017, 2009.

[132] C. D. Lao, M. T. Ruffin IV, D. Normolle et al., "Dose escalation of a curcuminoid formulation," BMC Complementary and Alternative Medicine, vol. 6, article no. 10, 2006.

[133] Y.-M. Tsai, C.-F. Chien, L.-C. Lin, and T.-H. Tsai, "Curcumin and its nano-formulation: the kinetics of tissue distribution and blood-brain barrier penetration," International Journal of Pharmaceutics, vol. 416, no. 1, pp. 331-338, 2011.

[134] N. K. Gupta and V. K. Dixit, "Bioavailability enhancement of curcumin by complexation with phosphatidyl choline," Journal of Pharmaceutical Sciences, vol. 100, no. 5, pp. 1987-1995, 2011.

[135] S. Manju and K. Sreenivasan, "Conjugation of curcumin onto hyaluronic acid enhances its aqueous solubility and stability," Journal of Colloid and Interface Science, vol. 359, no. 1, pp. 318325, 2011.

[136] J. Li, Y. Wang, C. Yang et al., "Polyethylene glycosylated curcumin conjugate inhibits pancreatic cancer cell growth through inactivation of Jab1," Molecular Pharmacology, vol. 76, no. 1, pp. 81-90, 2009.

[137] S. Debnath, D. Saloum, S. Dolai et al., "Dendrimer-curcumin conjugate: a water soluble and effective cytotoxic agent against breast cancer cell lines," Anti-Cancer Agents in Medicinal Chemistry, vol. 13, no. 10, pp. 1531-1539, 2013.

[138] L. Hu, Y. Jia, F. Niu, Z. Jia, X. Yang, and K. Jiao, "Preparation and enhancement of oral bioavailability of curcumin using microemulsions vehicle," Journal of Agricultural and Food Chemistry, vol. 60, no. 29, pp. 7137-7141, 2012.

[139] A. M. Chuah, B. Jacob, Z. Jie et al., "Enhanced bioavailability and bioefficacy of an amorphous solid dispersion of curcumin," Food Chemistry, vol. 156, pp. 227-233, 2014.

[140] J. M. Reid, S. A. Buhrow, J. A. Gilbert et al., "Mouse pharmacokinetics and metabolism of the curcumin analog, 4-piperidinone,3,5-bis[(2-fluorophenyl)methylene]-acetate(3E,5E) (EF24; NSC 716993)," Cancer Chemotherapy and Pharmacology, vol. 73, no. 6, pp. 1137-1146, 2014.

[141] K. Mohankumar, S. Sridharan, S. Pajaniradje et al., "BDMC-A, an analog of curcumin, inhibits markers of invasion, angiogenesis, and metastasis in breast cancer cells via NF- $\kappa$ B pathway-a comparative study with curcumin," Biomedicine and Pharmacotherapy, vol. 74, pp. 178-186, 2015.

[142] C. Kudo, H. Yamakoshi, A. Sato et al., "Synthesis of 86 species of 1,5-diaryl-3-oxo-1,4-pentadienes analogs of curcumin can yield a good lead in vivo," BMC Pharmacology, vol. 11, article 4, 2011.
[143] L. Hackler Jr., B. Ózsvári, M. Gyuris et al., “The curcumin analog C-150, influencing NF- $\kappa$ B, UPR and Akt/Notch pathways has potent anticancer activity in vitro and in vivo," PLoS ONE, vol. 11, no. 3, Article ID e0149832, 2016.

[144] S. B. Subramanian, A. P. Francis, and T. Devasena, "Chitosanstarch nanocomposite particles as a drug carrier for the delivery of bis-desmethoxy curcumin analog," Carbohydrate Polymers, vol. 114, pp. 170-178, 2014.

[145] C. R. Ireson, D. J. L. Jones, S. Orr et al., "Metabolism of the cancer chemopreventive agent curcumin in human and rat intestine," Cancer Epidemiology Biomarkers and Prevention, vol. 11, no. 1, pp. 105-111, 2002.

[146] O. N. Gordon, P. B. Luis, H. O. Sintim, and C. Schneider, "Unraveling curcumin degradation: autoxidation proceeds through spiroepoxide and vinylether intermediates en route to the main bicyclopentadione," The Journal of Biological Chemistry, vol. 290, no. 8, pp. 4817-4828, 2015.

[147] M. Griesser, V. Pistis, T. Suzuki, N. Tejera, D. A. Pratt, and C. Schneider, "Autoxidative and cyclooxygenase-2 catalyzed transformation of the dietary chemopreventive agent curcumin," Journal of Biological Chemistry, vol. 286, no. 2, pp. 1114-1124, 2011.

[148] M. Heger, R. F. van Golen, M. Broekgaarden, and M. C. Michel, "The molecular basis for the pharmacokinetics and pharmacodynamics of curcumin and its metabolites in relation to cancers," Pharmacological Reviews, vol. 66, no. 1, pp. 222-307, 2014.

[149] R. A. Sharma, H. R. McLelland, K. A. Hill et al., "Pharmacodynamic and pharmacokinetic study of oral Curcuma extract in patients with colorectal cancer," Clinical Cancer Research, vol. 7, no. 7, pp. 1894-1900, 2001.

[150] M. Kanai, A. Imaizumi, Y. Otsuka et al., "Dose-escalation and pharmacokinetic study of nanoparticle curcumin, a potential anticancer agent with improved bioavailability, in healthy human volunteers," Cancer Chemotherapy and Pharmacology, vol. 69, no. 1, pp. 65-70, 2012.

[151] H. Sasaki, Y. Sunagawa, K. Takahashi et al., "Innovative preparation of curcumin for improved oral bioavailability," Biological and Pharmaceutical Bulletin, vol. 34, no. 5, pp. 660-665, 2011.

[152] S. Prasad, A. K. Tyagi, and B. B. Aggarwal, "Recent developments in delivery, bioavailability, absorption and metabolism of curcumin: the golden pigment from golden spice," Cancer Research and Treatment, vol. 46, no. 1, pp. 2-18, 2014.

[153] G. Shoba, D. Joy, T. Joseph, M. Majeed, R. Rajendran, and P. S. S. R. Srinivas, "Influence of piperine on the pharmacokinetics of curcumin in animals and human volunteers," Planta Medica, vol. 64, no. 4, pp. 353-356, 1998.

[154] N. M. Yunos, P. Beale, J. Q. Yu, and F. Huq, "Synergism from sequenced combinations of curcumin and epigallocatechin-3gallate with cisplatin in the killing of human ovarian cancer cells," Anticancer Research, vol. 31, no. 4, pp. 1131-1140, 2011.

[155] N. M. Yunos, P. Beale, J. Q. Yu, and F. Huq, "Synergism from the combination of oxaliplatin with selected phytochemicals in human ovarian cancer cell lines," Anticancer Research, vol. 31, no. 12, pp. 4283-4289, 2011.

[156] F. Hu, F. Wei, Y. Wang, B. Wu, Y. Fang, and B. Xiong, "EGCG synergizes the therapeutic effect of cisplatin and oxaliplatin through autophagic pathway in human colorectal cancer cells," Journal of Pharmacological Sciences, vol. 128, no. 1, pp. 27-34, 2015.

[157] K. Selvendiran, S. Ahmed, A. Dayton et al., "HO-3867, a curcumin analog, sensitizes cisplatin-resistant ovarian carcinoma, 
leading to therapeutic synergy through STAT3 inhibition," Cancer Biology \& Therapy, vol. 12, no. 9, pp. 837-845, 2011.

[158] A. R. M. Ruhul Amin, D. Wang, H. Zhang et al., "Enhanced antitumor activity by the combination of the natural compounds (-)-epigallocatechin-3-gallate and luteolin: potential role of p53," Journal of Biological Chemistry, vol. 285, no. 45, pp. 3455734565, 2010.

[159] T.-C. Hsieh and J. M. Wu, "Suppression of cell proliferation and gene expression by combinatorial synergy of EGCG, resveratrol and $\gamma$-tocotrienol in estrogen receptor-positive MCF-7 breast cancer cells," International Journal of Oncology, vol. 33, no. 4, pp. 851-859, 2008.

[160] T.-C. Hsieh and J. M. Wu, "Targeting CWR22Rv1 prostate cancer cell proliferation and gene expression by combinations of the phytochemicals EGCG, genistein and quercetin," Anticancer Research, vol. 29, no. 10, pp. 4025-4032, 2009.

[161] F. Ye, G.-H. Zhang, B.-X. Guan, and X.-C. Xu, "Suppression of esophageal cancer cell growth using curcumin, ()-epigallocatechin-3-gallate and lovastatin," World Journal of Gastroenterology, vol. 18, no. 2, pp. 126-135, 2012.

[162] S. S. Chung and J. V. Vadgama, "Curcumin and epigallocatechin gallate inhibit the cancer stem cell phenotype via downregulation of STAT3-NF $\mathrm{B}$ signaling," Anticancer Research, vol. 35, no. 1, pp. 39-46, 2015.

[163] Q. Du, B. Hu, H.-M. An et al., "Synergistic anticancer effects of curcumin and resveratrol in Hepal-6 hepatocellular carcinoma cells," Oncology Reports, vol. 29, no. 5, pp. 1851-1858, 2013.

[164] T. J. Somers-Edgar, M. J. Scandlyn, E. C. Stuart, M. J. Le Nedelec, S. P. Valentine, and R. J. Rosengren, "The combination of epigallocatechin gallate and curcumin suppresses $\mathrm{ER} \alpha$-breast cancer cell growth in vitro and in vivo," International Journal of Cancer, vol. 122, no. 9, pp. 1966-1971, 2008.

[165] D.-H. Zhou, X. Wang, M. Yang, X. Shi, W. Huang, and Q. Feng, "Combination of low concentration of (-)-epigallocatechin gallate (EGCG) and curcumin strongly suppresses the growth of non-small cell lung cancer in vitro and in vivo through causing cell cycle arrest," International Journal of Molecular Sciences, vol. 14, no. 6, pp. 12023-12036, 2013.

[166] M. Masuda, T. Wakasaki, S. Toh, M. Shimizu, and S. Adachi, "Chemoprevention of head and neck cancer by green tea extract: EGCG-the role of EGFR signaling and 'lipid raft", Journal of Oncology, vol. 2011, Article ID 540148, 7 pages, 2011.

[167] M.-M. Mocanu, C. Ganea, L. Georgescu et al., "Epigallocatechin 3-O-gallate induces $67 \mathrm{kDa}$ laminin receptor-mediated cell death accompanied by downregulation of ErbB proteins and altered lipid raft clustering in mammary and epidermoid carcinoma cells," Journal of Natural Products, vol. 77, no. 2, pp. 250-257, 2014.

[168] H. Huynh, T. T. Nguyen, E. Chan, and E. Tran, "Inhibition of ErbB-2 and ErbB-3 expression by quercetin prevents transforming growth factor alpha (TGF- $\alpha$ )- and epidermal growth factor (EGF)-induced human PC-3 prostate cancer cell proliferation," International Journal of Oncology, vol. 23, no. 3, pp. 821-829, 2003.

[169] D. Fridrich, N. Teller, M. Esselen, G. Pahlke, and D. Marko, "Comparison of delphinidin, quercetin and (-)-epigallocatechin3-gallate as inhibitors of the EGFR and the ErbB2 receptor phosphorylation," Molecular Nutrition and Food Research, vol. 52, no. 7, pp. 815-822, 2008.

[170] J.-Y. Lee, Y.-M. Lee, G.-C. Chang et al., "Curcumin induces EGFR degradation in lung adenocarcinoma and modulates p38 activation in intestine: the versatile adjuvant for gefitinib therapy," PLoS ONE, vol. 6, no. 8, Article ID e23756, 2011.

[171] A. Khan, A. N. Aljarbou, Y. H. Aldebasi, S. M. Faisal, and M. A. Khan, "Resveratrol suppresses the proliferation of breast cancer cells by inhibiting fatty acid synthase signaling pathway," Cancer Epidemiology, vol. 38, no. 6, pp. 765-772, 2014.

[172] T.-D. Way, M.-C. Kao, and J.-K. Lin, "Apigenin induces apoptosis through proteasomal degradation of HER2/neu in HER2/ neu-overexpressing breast cancer cells via the phosphatidylinositol 3-kinase/Akt-dependent pathway," The Journal of Biological Chemistry, vol. 279, no. 6, pp. 4479-4489, 2004.

[173] N. Dhillon, B. B. Aggarwal, R. A. Newman et al., "Phase II trial of curcumin in patients with advanced pancreatic cancer," Clinical Cancer Research, vol. 14, no. 14, pp. 4491-4499, 2008.

[174] J. C. Montero, S. García-Alonso, A. Ocaña, and A. Pandiella, "Identification of therapeutic targets in ovarian cancer through active tyrosine kinase profiling," Oncotarget, vol. 6, no. 30, pp. 30057-30071, 2015.

[175] K. Subik, J.-F. Lee, L. Baxter et al., "The expression patterns of ER, PR, HER2, CK5/6, EGFR, KI-67 and AR by immunohistochemical analysis in breast cancer cell lines," Breast Cancer: Basic and Clinical Research, vol. 4, no. 1, pp. 35-41, 2010.

[176] S. Li, E. Buchbinder, L. Wu et al., "EGFR and HER2 levels are frequently elevated in colon cancer cells," Discoveries Reports, vol. 1, no. 1, pp. 1-8, 2014.

[177] J.-I. Okano, I. Gaslightwala, M. J. Birnbaum, A. K. Rustgi, and H. Nakagawa, "Akt/protein kinase B isoforms are differentially regulated by epidermal growth factor stimulation," The Journal of Biological Chemistry, vol. 275, no. 40, pp. 30934-30942, 2000.

[178] S. Song, S. Honjo, J. Jin et al., "The hippo coactivator YAP1 mediates EGFR overexpression and confers chemoresistance in esophageal cancer," Clinical Cancer Research, vol. 21, no. 11, pp. 2580-2590, 2015.

[179] P. Huang, X. Xu, L. Wang, B. Zhu, X. Wang, and J. Xia, “The role of EGF-EGFR signalling pathway in hepatocellular carcinoma inflammatory microenvironment," Journal of Cellular and Molecular Medicine, vol. 18, no. 2, pp. 218-230, 2014.

[180] S.-S. Guan, J. Chang, C.-C. Cheng et al., "Afatinib and its encapsulated polymeric micelles inhibits HER2-overexpressed colorectal tumor cell growth in vitro and in vivo," Oncotarget, vol. 5, no. 13, pp. 4868-4880, 2014.

[181] Y. Wang, T. Romigh, X. He et al., "Resveratrol regulates the PTEN/AKT pathway through androgen receptor-dependent and -independent mechanisms in prostate cancer cell lines," Human Molecular Genetics, vol. 19, no. 22, pp. 4319-4329, 2010.

[182] G. M. Seigel, S. Sharma, A. S. Hackam, and D. K. Shah, "HER2/ ERBB2 immunoreactivity in human retinoblastoma," Tumor Biology, vol. 37, no. 5, pp. 6135-6142, 2016.

[183] S. Sreenivasan and S. Krishnakumar, "Synergistic effect of curcumin in combination with anticancer agents in human retinoblastoma cancer cell lines," Current Eye Research, vol. 40, no. 11, pp. 1153-1165, 2015.

[184] A. Montgomery, T. Adeyeni, K. San, R. M. Heuertz, and U. R. Ezekiel, "Curcumin sensitizes silymarin to exert synergistic anticancer activity in colon cancer cells," Journal of Cancer, vol. 7, no. 10, pp. 1250-1257, 2016.

[185] W. P. Tsang and T. T. Kwok, "Epigallocatechin gallate upregulation of miR-16 and induction of apoptosis in human cancer cells," Journal of Nutritional Biochemistry, vol. 21, no. 2, pp. 140-146, 2010. 
[186] D. Milenkovic, B. Jude, and C. Morand, "miRNA as molecular target of polyphenols underlying their biological effects," Free Radical Biology and Medicine, vol. 64, pp. 40-51, 2013.

[187] Y. Tutar, "miRNA and cancer; computational and experimental approaches," Current Pharmaceutical Biotechnology, vol. 15, no. 5, p. 429, 2014.

[188] M. Sun, Z. Estrov, Y. Ji, K. R. Coombes, D. H. Harris, and R. Kurzrock, "Curcumin (diferuloylmethane) alters the expression profiles of microRNAs in human pancreatic cancer cells," Molecular Cancer Therapeutics, vol. 7, no. 3, pp. 464-473, 2008.

[189] S. Toden, Y. Okugawa, T. Jascur et al., "Curcumin mediates chemosensitization to 5-fluorouracil through miRNAinduced suppression of epithelial-to-mesenchymal transition in chemoresistant colorectal cancer," Carcinogenesis, vol. 36, no. 3, pp. 355-367, 2015. 


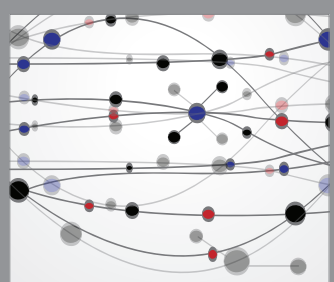

The Scientific World Journal
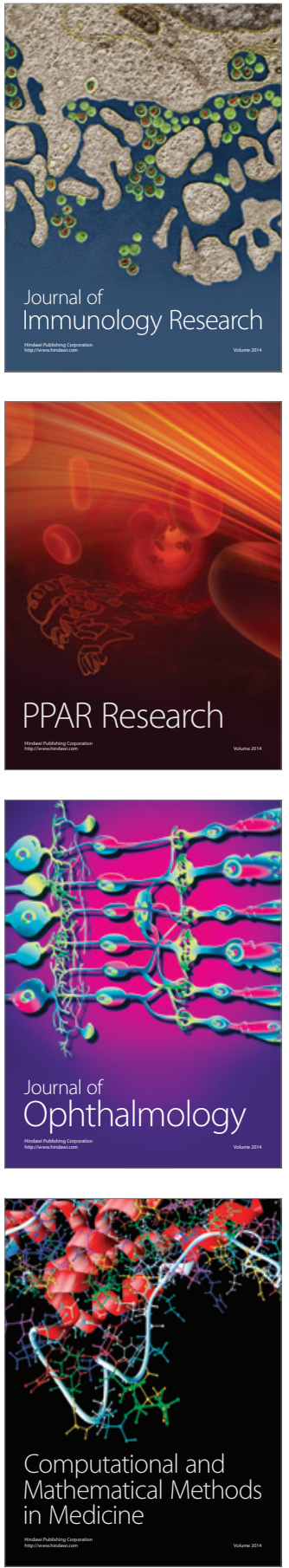

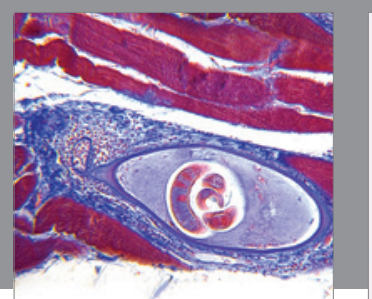

Gastroenterology Research and Practice
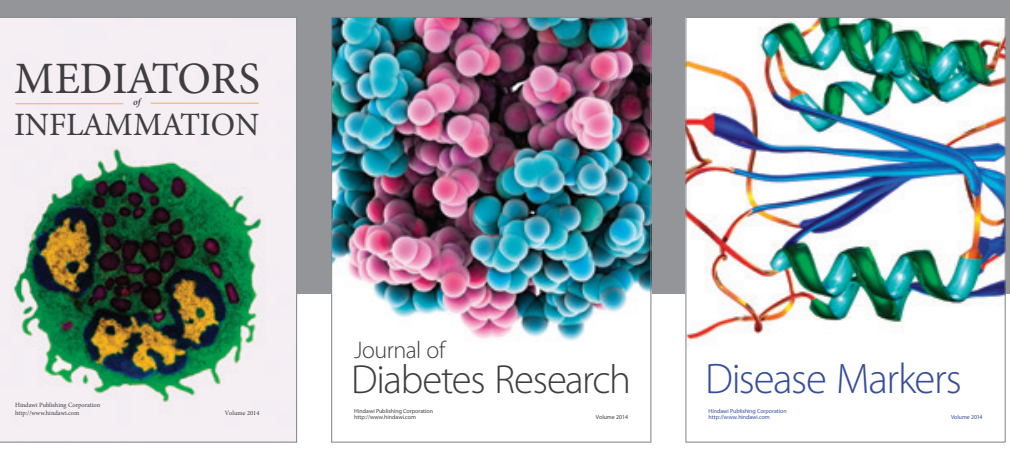

Disease Markers

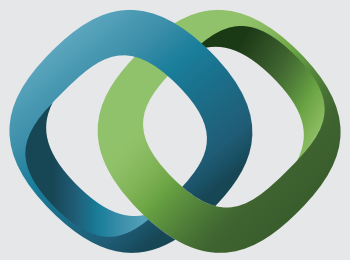

\section{Hindawi}

Submit your manuscripts at

https://www.hindawi.com
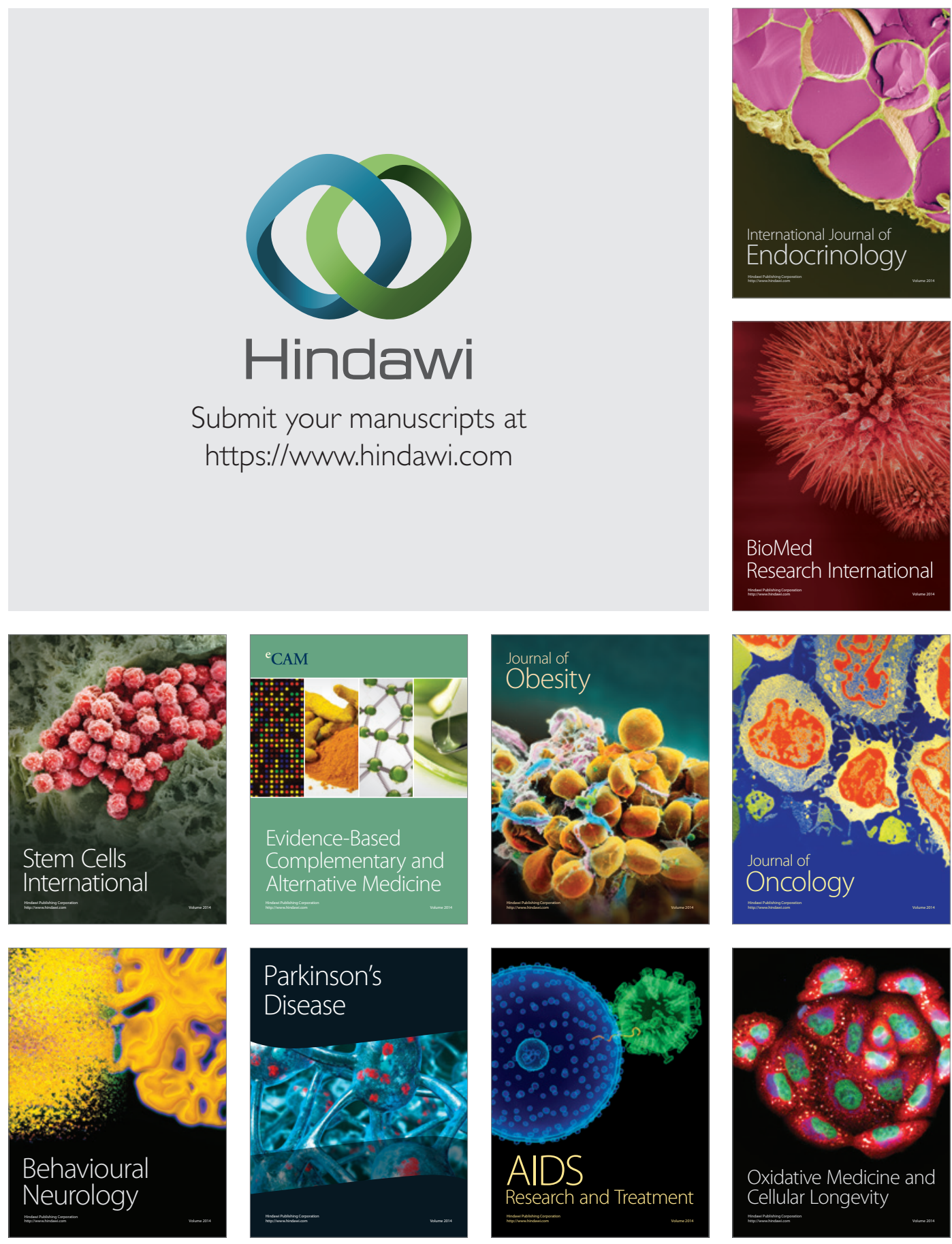